The Distribution and Occurrence

of the

\title{
BIRDS OF JACKSON COUNTY, OREGON, AND SURROUNDING AREAS
}

\author{
by M. Ralph Browning \\ National Fish and Wildlife Laboratory \\ FISH AND WILDLIFE SERVICE
}

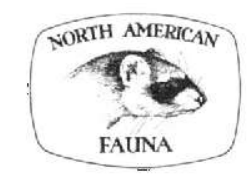

NUMBER 70 


\title{
UNITED STATES \\ DEPARTMENT OF THE INTERIOR \\ FISH AND WILDLIFE SERVICE
}

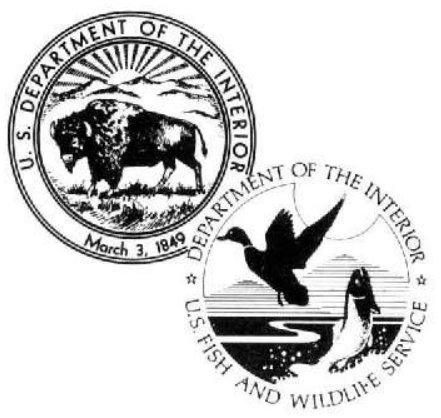

North American Fauna, Number 70

\author{
Published by \\ FISH AND WILDLIFE SERVICE \\ 1975
}

U.S. GOVERNMENT PRINTING OFFIGE

WASHINGTON : 1975

For sale by the Superintendent of Documents, C.S. Government Printing Office Washington, D.C. 20402 - Price $\$ 1.15$ Stock Number 024-010-00403-7

Cat. No. I 49.30:70 


\section{Contents}

INTRODUCTION

TOFOGRAPHY

Climate and Vegetation . .

Chaparral-Oak Community

Mixed Conifer Forest. ................... 8

True Fir Forest

Timberline Forest.

GAZETTEER

Avian Communities.

Plan of The Species Accounts.

Abundance scale

Frequency scale $\ldots \ldots \ldots . .22$

Seasonal occurrence $\ldots \ldots \ldots \ldots . \ldots 22$

SPECIES Accounts.

ACKNOWLEDGMENTS .

Literature Cited 



\section{INTRODUCTION}

Jackson County in southwestern Oregon occupies $4,525 \mathrm{~km}^{2}$. The county is situated between $42^{\circ} 00^{\prime}$ and $43^{\circ} 00^{\prime}$ north latitude, and between $122^{\circ} 17^{\prime}$ and $123^{\circ} 14^{\prime}$ west longitude. About $113 \mathrm{~km}$ from the Pacific Ocean, the county is bounded by California to the south and by the Oregon counties of Josephine, Douglas, and Klamath to the west, north, and east, respectively (Fig. 1). About 95,000 people live in Jackson County, most of them concentrated in the cities of Medford and Ashland in Bear Creek Valley. The remaining population is chiefly scattered throughout the Lower Rogue River and Bear Creek valleys. Agriculture (orchards, especially pears, and mixed farmland) dependent on summer irrigation, light industry (primarily lumber), and residential areas occupy most of the land area below $610 \mathrm{~m}$ elevation in the Lower Rogue and Bear Creek valleys. About 70 percent of the county above $610 \mathrm{~m}$ is coniferous forest.

The distribution and occurrence of the Jackson County avifauna are of interest because the county is a small geographic area with numerous plant communities. In the Rogue River Valley, a large variety of breeding species similar to the avifauna of areas of California several hundred kilometers to the south was reported by Gabrielson (1931). Since then six papers (Stevenson and Fitch 1933; Richardson 1961; Richardson and Sturges 1964; and Browning $1966 \mathrm{a} ; 1966 \mathrm{~b} ; 1972)$ have dealt with certain birds of specific areas of the county. Thomas McCamant compiled 10 years of field notes into. an unpublished checklist with specific data on his more significant observations from 1947-57. The University of Oregon Press printed a checklist, "Birds of Southern Oregon," compiled at Southern Oregon College by Franklin W. Sturges.

I began field investigations in Jackson County in 1957. Since then I have visited most of the county and have conducted field observations or collected in all areas listed in the gazetteer. From 1965 to 1967 I attempted especially to explore previously uninvestigated regions of Jackson County. The Union Creek area (1965) and the southeastern corner of the county $(1966,1967)$ were surveyed for breeding species.

This report is based on information from the literature, specimens, photographs, unpublished notes of countless individuals, and my own investigations of Jackson County. Specimens cited in this report are in the Carl Richardson Bird and Mammal Collection at Southern Oregon College, Ashland, Oreg. 


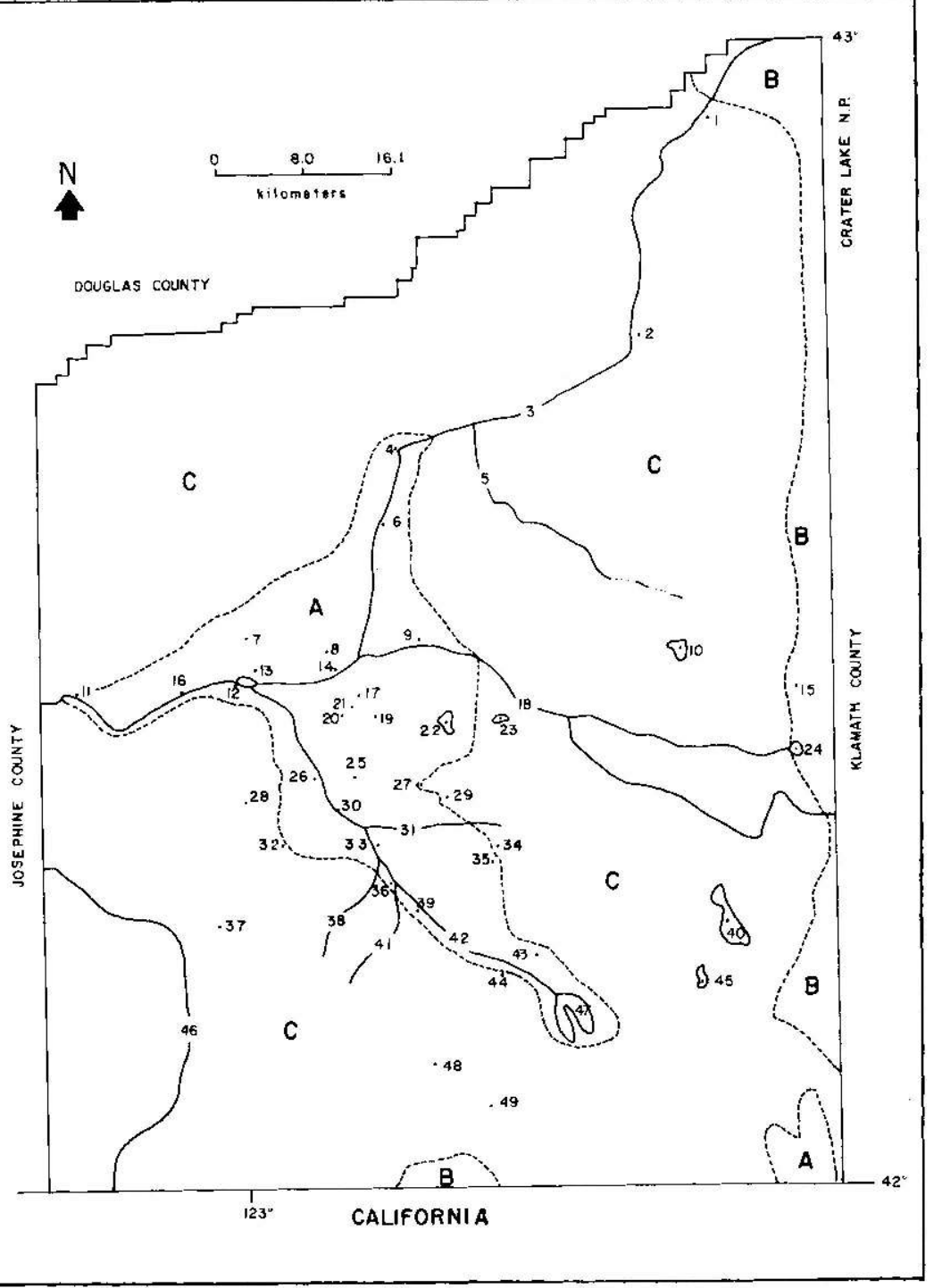




\section{TOPOGRAPHY}

Jackson County occupies an inland trapezoidal area of approximately $77.2 \mathrm{~km}$ east and west, $77.2 \mathrm{~km}$ north and south on the western boundary, and $108 \mathrm{~km}$ north and south on the eastern boundary. Dicken's (1959:12) landform regions of Oregon divide the county into two major mountain systems, the Cascade and Siskiyou mountains, and one primary drainage system, the Rogue River and its tributaries.

The Siskiyou Mountains, a part of the Klamath Mountain system, form a dissected plateau more rugged than the Coastal Range of Oregon. This range, running from east to west in the southern end of the county, rises to elevations of over 1,524 m (Atwood, 1940:468). Mount Ashland, elevation 2,296 m, is the highest peak in the Siskiyou Mountains.

Fic. 1, Jackson County, Oregon, showing the localities listed in the Gazeteer.

Numerical order of the localities are from north to south and west to east.
1. Union Creek (town)
26. Central Point
2. Prospect
27. Roxy Ann Peak
3. Rogue River (stream)
28. Johns Peak
4. Trail
29. Oregon Switzerland
5. Big Butte Creek
30. Medford
6. Shady Cove
31. Larson Creek
7. Sam's Valley
32. Jacksonville
8. Upper Table Rock
9. Eagle Point
33. Voorhies Crossing
10. Willow Creek Reservoir
34. Mount Baldy
35. Tombstone
11. Rogue River (town)
36. Phoenix
12. Gold Ray Dam
37. Ruch
13. Lower Table Rock
38. Coleman Creek
14. Old Military Bridge
39. Talent
15. Mount McLoughlin
40. Howard Prairie Reservoir
16. Goldhill
17. Agate Desert
18. Little Butte Creek
41. Anderson Creek
42. Bear Creek
43. Pompadour Bluff
19. Hoover's Lakes
44. Ashland
20. Game Ponds
21. White City
22. Agate Reservoir
23. Gardner Reservoir
45. Hyatt Reservoir
46. Applegate River
47. Emigrant Reservoir
48. Wagner Butte
24. Fish Lake
49. Mount Ashland

25. Medford Municipal Airport

( $A=$ Chaparral-Oak Community, $B=$ True Fir Forest, $\mathrm{C}=$ Mixed Conifer Forest.) 
Joining the Siskiyous in southeastern Jackson County, the Cascade Mountains run from north to south east of Bear Creek Valley and part of the Rogue River Valley. Near Union Creek the Cascades are differentiated geologically into the Old and High Cascades. The Old Cascades are in the western part of the system and are typically less rugged and of lower elevation than the High Cascades. Mount McLoughlin (elevation, $2,975 \mathrm{~m}$ ) is the highest point in the more rugged High Cascades in eastern Jackson County.

The Rogue River Valley, a trough-like basin, constitutes the major flat lowland portion of the county. To differentiate the upper and lower sections of the Rogue River Valley, I use the term Lower Rogue River Valley to refer to that part of the valley downstream from Shady Cove $(426 \mathrm{~m})$ to the boundary of Josephine and Jackson counties (about $305 \mathrm{~m}$ ). The Lower Valley extends north into Sam's Valley near Upper and Lower Table Rocks. The narrow Upper Rogue River Valley extends from Shady Cove to above Union Creek. The remaining lowland area of the county is the Bear Creek Valley. Bear Creek and its tributaries form the main drainage of the eastern Siskiyous where that range joins the Cascades. This valley begins near Ashland (elevation, $610 \mathrm{~m}$ ) and terminates at the Rogue River near Gold Ray Dam (366 m).

The Rogue River and Bear Creek are fed primarily by winter rains and melting snow in the higher elevations during summer. Bear Creek becomes almost intermittent during dry summer months, and many of the tributaries of the Lower Rogue River become low and sluggish. Most of the mountain tributaries above Shady Cove as well as the Rogue River are spring fed, and water levels are fairly stable. The Applegate River, a major tributary of the Rogue River with its headwaters in the Siskiyou Mountains, terminates near Grants Pass in Josephine County.

Numerous bodies of water, mostly irrigation reservoirs, are near the Cascade Mountain Crest. Among those of particular ornithological interest are Fish Lake and Howard and Hyatt Prairie reservoirs. At the head of Bear Creek Valley is Emigrant Reservoir. Where Bear Creek intersects with the Rogue River there are backwaters formed by Gold Ray Dam. Small lowland bodies of water north of Medford include a series of ponds known as Hoover's Lakes, another nearby series of ponds in the Ken Denman Game Management area of the Oregon State Game Commission here referred to as the Game Ponds, and Agate Reservoir northeast of Medford. 


\section{CLIMATE AND VEGETATION}

Temperatures in the county are usually mild. Summer is characterized by warm days and cool nights. Rainfall is primarily a winter phenomenon; during the drier summer months it is usually a product of local electrical storms. Summer days are usually cloudless and humidity is very low; less than $10 \%$ is not uncommon in the valleys and mountains. Most winter days are heavily overcast and fog is common in the Lower Rogue River Valley during most of December.

Climatic data are presented in Table 1. Data from Crater Lake National Park in Klamath County are included as representative of the southern Cascade Mountains in Oregon.

Precipitation in Jackson County varies in form and amount. The driest months at Medford are July, August, and September. Most of the rainfall $(28 \mathrm{~cm})$ at Medford occurs from November to February; December, the wettest month, has an average of $8.9 \mathrm{~cm}$ (Rudd 1962). The distribution of precipitation in the mountains of Jackson County is similar to that in Medford but is mostly in the form of snow.

The vegetation of Jackson County is best described in terms of forest coverage. Earlier concepts of vegetation distribution (see Bailey 1936) in the county recognized five life zones-Upper Sonoran, Transition, Canadian, Hudsonian, and Arctic-Alpine. Peck (1941) described nine vegetation areas for Oregon using a system that more closely approaches the plant community concept and allows a more ecological interpretation of a geographic area. A classification of plant communities adapted from Munz and Keck (1959) is used here to describe the vegetation of Jackson County (Fig. 1). The system adapted is

TABLE 1. Climatic data from representative weather stations in Jackson County, Oreg.

\begin{tabular}{|c|c|c|c|c|c|c|c|c|}
\hline \multirow[b]{2}{*}{ Station } & \multicolumn{5}{|c|}{ Temperature (F) } & \multicolumn{2}{|c|}{$\begin{array}{l}\text { Precipitation } \\
\text { (inches) }\end{array}$} & \multirow[b]{2}{*}{$\begin{array}{l}\text { Frost } \\
\text { free } \\
\text { days }\end{array}$} \\
\hline & $\begin{array}{l}\text { Aver. } \\
\text { age } \\
\text { annual }\end{array}$ & $\begin{array}{l}\text { Aver- } \\
\text { age } \\
\text { Janu- } \\
\text { ary }\end{array}$ & $\begin{array}{l}\text { Aver- } \\
\text { age } \\
\text { mini- } \\
\text { mum } \\
\text { Janu- } \\
\text { ary }\end{array}$ & $\begin{array}{c}\text { Aver- } \\
\text { age } \\
\text { July }\end{array}$ & $\begin{array}{l}\text { Aver- } \\
\text { age } \\
\text { maxi- } \\
\text { mum } \\
\text { July }\end{array}$ & $\begin{array}{c}\text { Aver- } \\
\text { age } \\
\text { annual }\end{array}$ & $\begin{array}{c}\text { Aver- } \\
\text { age }\end{array}$ & \\
\hline Medford & 54 & 37 & 30 & 72 & 89 & 20 & 7 & 161 \\
\hline Prospect_........ & 50 & 35 & 26 & 66 & 88 & 42 & 64 & - \\
\hline Siskiyou Station & 48 & 34 & 26 & 65 & 76 & 33 & - & - \\
\hline Crater Lake ${ }^{1} \ldots \ldots$ & 39 & 25 & 18 & 54 & 66 & 70 & 589 & 71 \\
\hline
\end{tabular}

1 Conditions for southern Cascades in Jackson County less extreme.

Souree: U.S. Weather Bureau 1965, Rudd 1962, Farner 1952. 
similar to that presented by Franklin and Dyrness (1973). Some of the departures between the system used here and that of Franklin and Dyrness (1973) are mentioned in the following discussion of plant communities of Jackson County.

Four plant communities occur in Jackson County. Scientific names of the vegetation are from Randall (1964).

Chaparral-Oak Community.-The Chaparral-Oak area of the Lower Rogue River and Bear Creek valleys is considered a probable postglacial relict (Detling 1961) related to the California chaparral formation south of the Siskiyou Mountain barrier. In Jackson County this area from the valley floor to about $762 \mathrm{~m}$ is more arid and has hotter day-time temperatures than the surrounding areas. Land not under cultivation or uninhabited is dominated by island groves of Quercus garryana and Q. kelloggii, with an understory of Ceanothus cuneatus and Arctostaphylos viscida. Ceanothus cuneatus and Arctostaphylos viscida may be found throughout the valley and foothills growing in dense brushfields or mixed with Quercus groves. Much of the area is characterized by large open fields of dwarf grasses and shortlived annuals that usually die by mid-June because of lack of precipitation. Such fields frequently stand under $2.5 \mathrm{~cm}$ or more of water during winter.

The eastern Bear Creek foothills are characterized by larger and more abundant Quercus groves, scattered trees of Pinus ponderosa, and an understory of Rhus diversiloba (Fig. 2). Most of the southern and western slopes of Roxy Ann Peak and Baldy are dominated by nearly impenetrable $R$ hus diversiloba, of ten over $3 \mathrm{~m}$ high, interrupted only

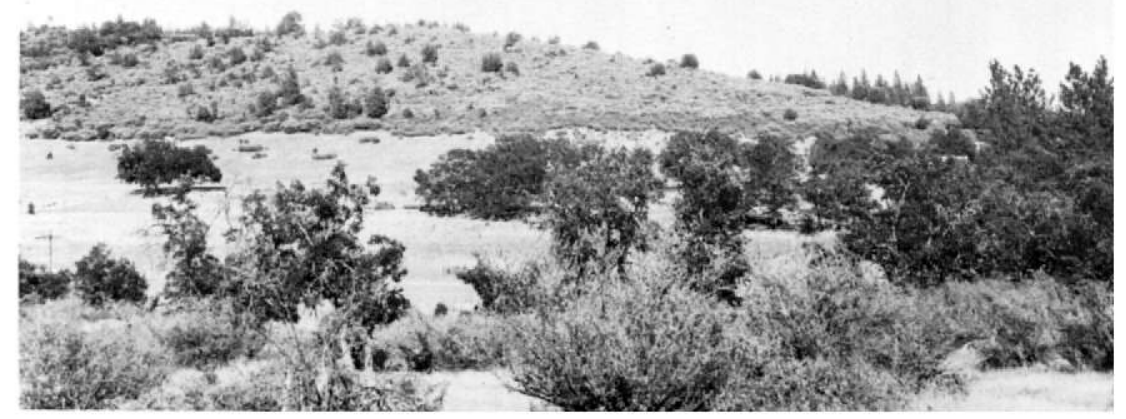

Fig. 2. Foothills east of Medford. Quercus groves and Pinus ponderosa are the predominate trees. Ceonothus and Arctostaphylos spp. occupy most of the foreground. Elevation, about $610 \mathrm{~m}$. 
by small Quercus groves and on Baldy by large open areas (balds), which include about $75 \%$ of the southern and western slopes above $762 \mathrm{~m}$ (Fig. 3).

The western valley foothills are cooler and less arid than those in the eastern part of the valley. Dominant vegetation includes Quercus garryana, Q. kelloggii, Arbutus menziesii, Ceonothus spp., Rhus diversiloba, and occasionally small Pseudotsuga menziesii. Arctostaphylos viscida, sometimes in very dense growth, may be associated with Arbutus menziesii in the western foothills as an understory. Arctostaphylos is a common dominant plant on the arid southern slope of the Siskiyou Mountains up to 1,219 $\mathrm{m}$ and along the base of Roxy Ann Peak.

Characteristic plants in southeastern Jackson County are similar to those in the Lower Rogue River and Bear Creek valleys. Primary differences are the greater abundance of Pinus ponderosa and Pseudotsuga menziesii. The avifauna of this region is more characteristic of the Lower Rogue River and Bear Creek valleys.

Riparian growth, included here with the geographic area encompassed by the Chaparral-Oak Community, occurs along the Rogue and Applegate rivers, Bear Creek, and some of their tributaries. Characteristic vegetation includes Salix spp., Populus trichocarpa, Fraxinus latifolia, and Rubus spp. understory.

The remaining portion of Jackson County is mountainous and dominated by coniferous forest. This upland part of the county is in the Oregonian Province (Dice 1943:31), which includes the Cascade Mountains of northern Jackson County west and north of Union Creek

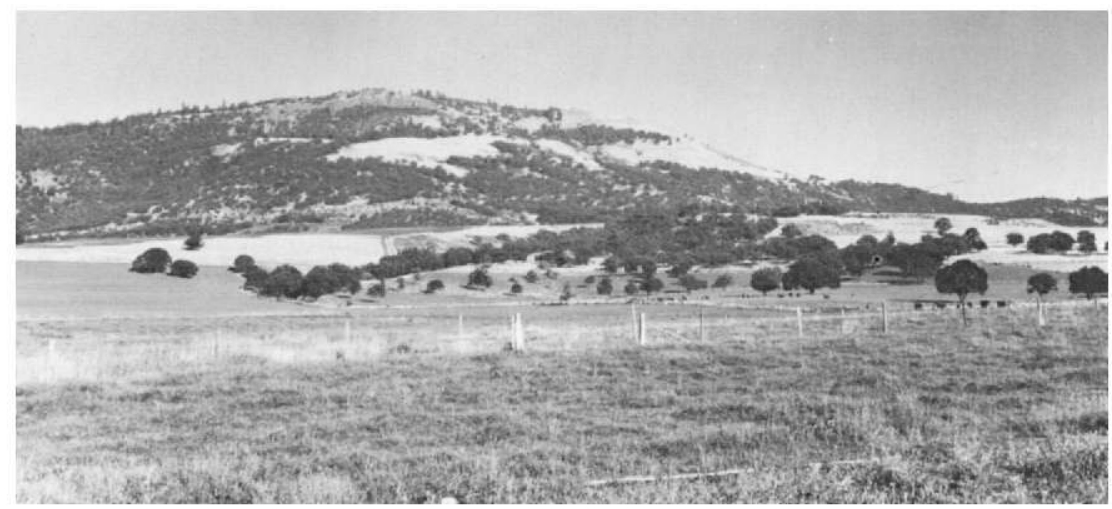

Fig. 3. Quercus groves and diversified farmland east of Medford. Ceonothus spp., Rhus diversiloba, and oak groves on the west slope of Mount Baldy are interrupted with open areas of short grasses and annuals. 
and most of the southern part of the county occupied by the Siskiyou Mountains.

Three plant communities occupy the remainder of the county:

Mixed Conifer Forest.-Abies, Pinus, and Pseudotsuga are dominant trees in the Mixed Conifer Forest occupying an elevational range of 762 to $1,372 \mathrm{~m}$. Pseudotsuga menziesii occurs in most locations (Fig. 4). Most of the area has been heavily logged. Pinus ponderosa, Pseudotsuga menziesii, Libocedrus decurrens, Pinus jeffreyi (Siskiyou Mountains), Thuja plicata, Arbutus menziesii, Quercus garryana, Q. kelloggii are dominant species. Quercus spp. occurs with Pinus ponderosa in the lower elevations and most commonly in the extreme southeastern region of the county. Mixed forest of Pinus spp., Pseudotsuga menziesii, Tsuga heterophylla, Abies grandis, A. nobilis, and $A$. concolor are dominant from about 1,219 to $1,372 \mathrm{~m}$ (Fig. 5).

Pinus ponderosa and $P$. lambertiana (mostly secondary growth) associated with Pseudotsuga menziesii are dominant along the Upper Rogue River between Shady Cove to Prospect and east of Union Creek. Pinus lambertiana and Pseudotsuga menziesii are dominant from Prospect to Union Creek.

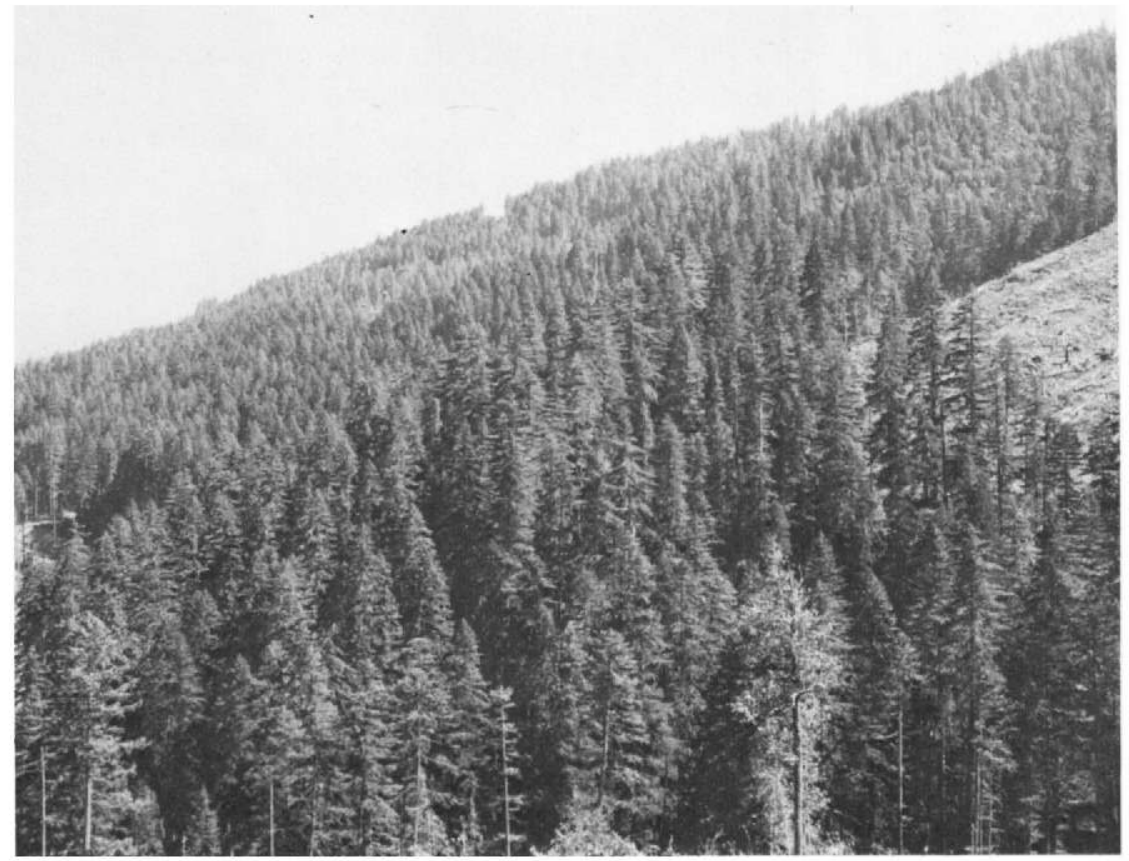

Fig. 4. Pseudotsuga menziesii on the western slope of the Cascade Mountains in Mixed Conifer Forest. 


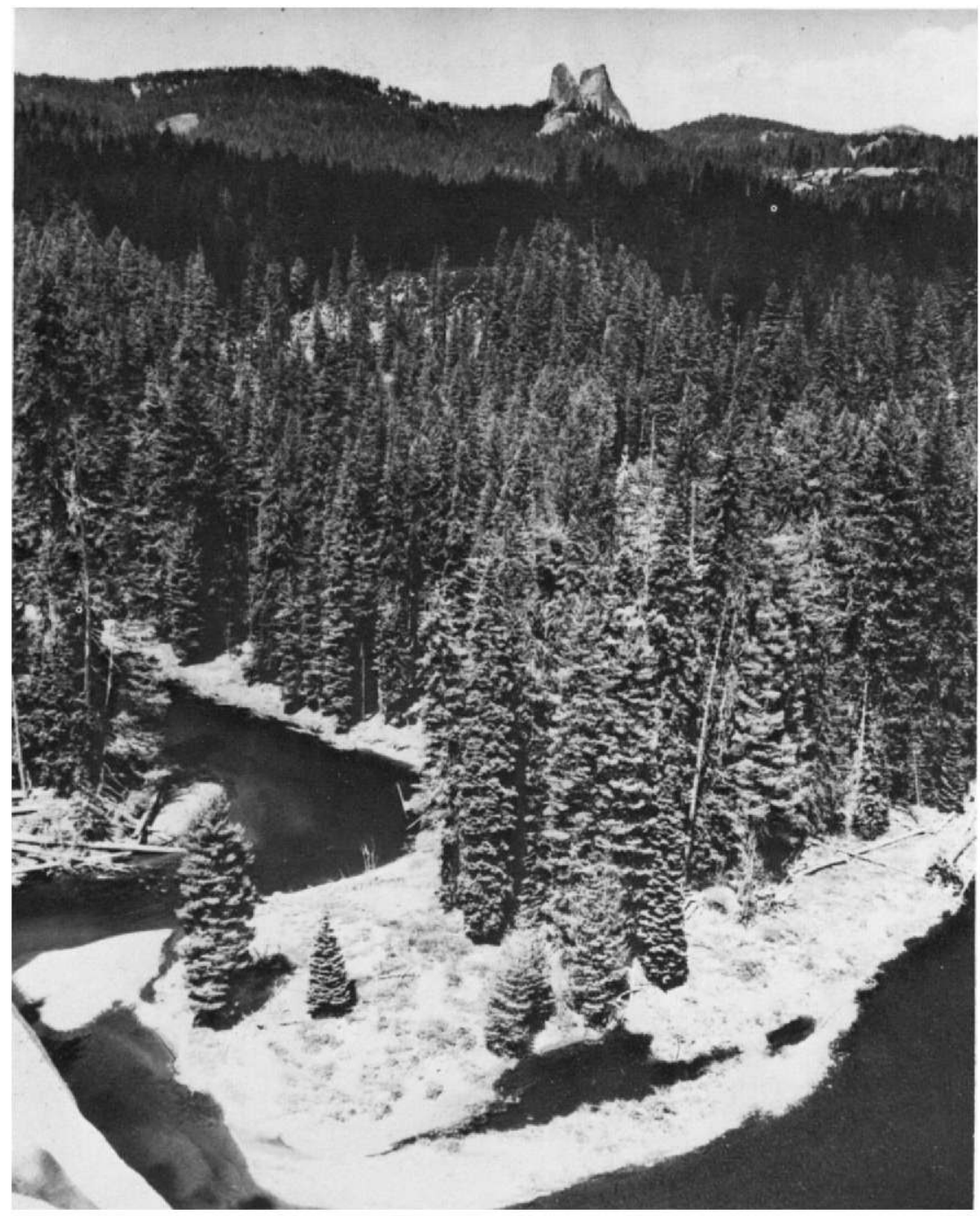

Fig. 5. Mixed Conifer Forest north of Union Creek at 1,219 m.

Franklin and Dyrness (1973) differentiated this community into two zones. The western Siskiyou Mountains are considered to be in the Mixed-Evergreen (Pseudotsuga-Sclerophyll) Zone. The most dominant tree species are Pseudotsuga menziesit and Lithocarpus densifforus. The west slope of the Cascades and the eastern Siskiyou Mountains are considered in their Mixed-Conifer (Pinus-PseudotsugaLibocedrus-Abies) Zone, which includes as dominant trees Pseudotsuga 
menziesii, Pinus lambertiana, P. ponderosa, Libocedrus decurrens, and Abies concolor. Ornithological investigations in these areas, especially the Siskiyou Mountains, are insufficient to compare the ecological aspects between these two plant communities.

True Fir Forest.-True firs occupy a narrow band of the Cascade Mountains above $1,372 \mathrm{~m}$ to about timberline (Fig. 6). Dominant species are Abies magnifica shastensis, A. concolor, and A. procera. Associated species are Tsuga mertensiana, Pinus contorta, Sorbus occidentalis, and Viburnum pauciflorum. Abies magnifica shastensis is a dominant species in the Siskiyou Mountains (Fig. 7) from about 1,798 to $2,012 \mathrm{~m}$ (Waring 1969).

Timberline Forest.-The highest elevations of Jackson County are typically forested by small subalpine forests; two Cascade Mountain peaks (Mount McLoughlin and Brown Mountain) are above timberline (Fig. 6). Pinus albicaulis, Tsuga mertensiana, Abies lasiocarpa, Cassiope spp., and Phyllococe spp. are the dominant plants above about $1,829 \mathrm{~m}$. Juniperus communis, Pinus monticola, Cassiope spp., and Phyllodoce spp. are dominant plants in the higher Siskiyou Mountains. The Timberline Forest includes the Tsuga mertensiana Zone and the Alpine Zone of Franklin and Dyrness (1973).

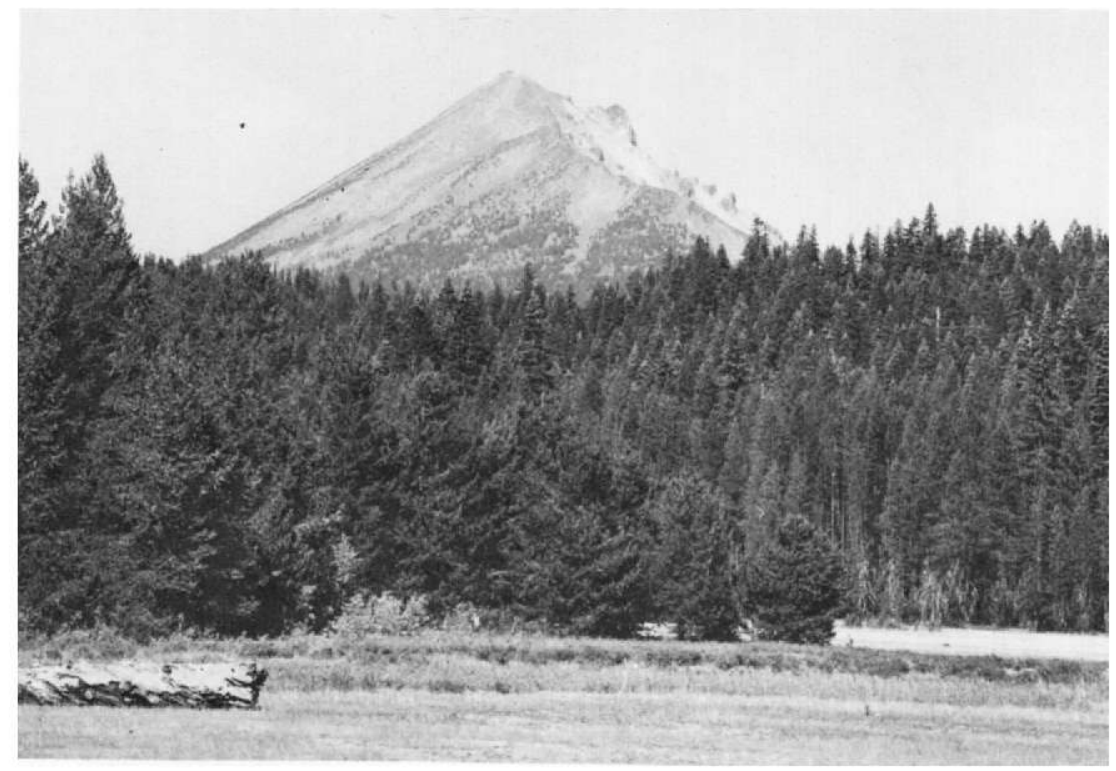

Fig. 6. True Fir Forest near Lake of the Woods (Klamath County) at 1,524 m. The summit of Mount McLoughlin is in the background. 


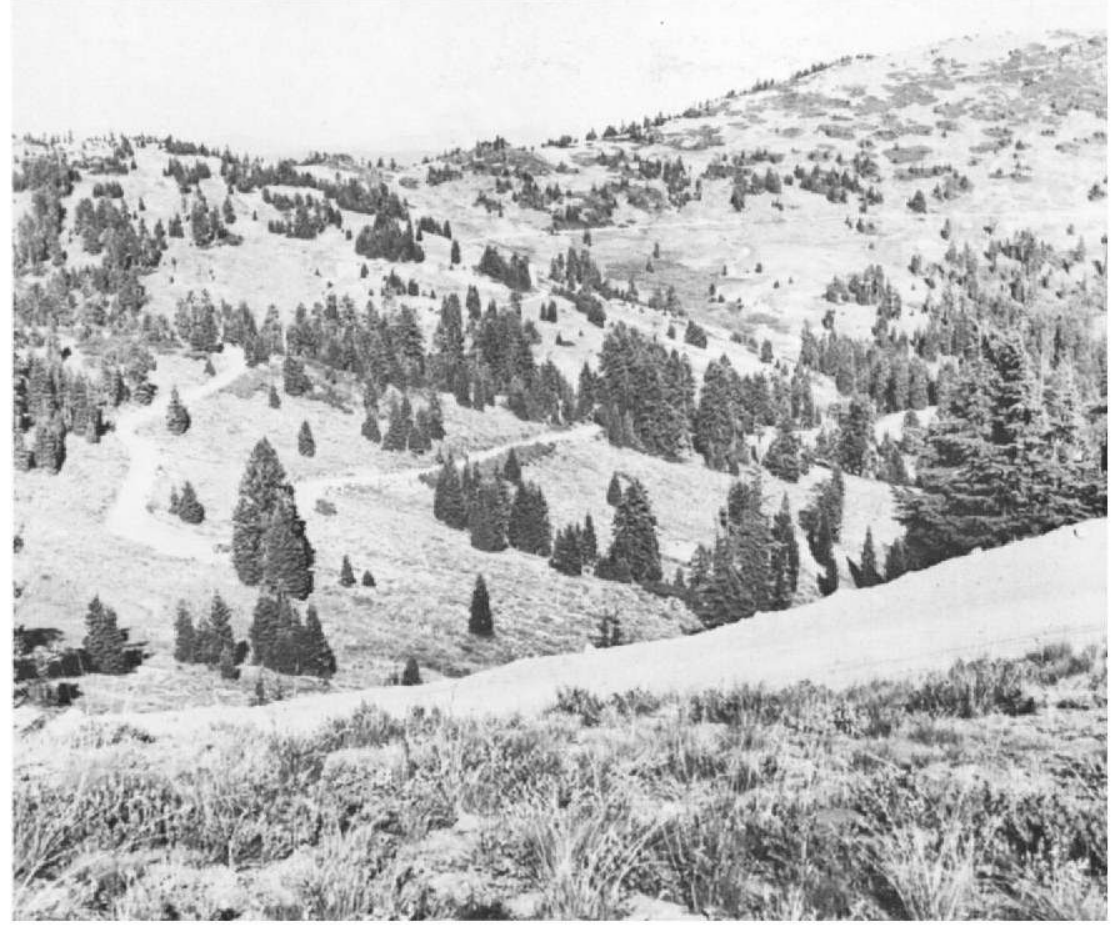

Fig. 7. Plants on the south side of Mount Ashland include Abies magnifica shastensis, A. procera, Chamaecyparis nootkatensis, and species of Ceonothus and Arctostaphylos. 



\section{GAZETTEER}

Geographical localities to which references are made in the species accounts are listed below. Names are followed by distances from a certain reference point, usually Medford or Ashland. Most of the localities are located on 15-minute quadrangles (scale 1:62500) published by the U.S. Geological Survey. Quadrangles with publication dates covering Jackson County are: Tiller (1944), Abbott Butte (1944), Prospect (1956), Wimer (1954), Trail (1945), Butte Falls (1954), Rustler Peak (1955), Goldhill (1954), Medford (1954), Lake Creek (1954), Mount McLoughlin (1955), Ruch (1954), Talent (1954), Ashland (1954), and Hyatt Reservoir (1955). Spelling, nomenclature, and measurements conform to those appearing on the maps. Measurements in parentheses are from the metric scale. Numbers in brackets identify localities shown in Fig. 1.

Agate Desert. Open shrub area 4 miles $(6.4 \mathrm{~km})$ north of Medford and west of White City [17].

Agate Reservoir. A reservoir 8 miles (12.9 km) northeast of Medford; elevation, 1,500 feet $(457 \mathrm{~m})$ [22].

Anderson Creek. A tributary of Bear Creek beginning 7 miles (11.3 km) south-southwest of Phoenix at 4,189 feet $(1,276.8 \mathrm{~m})$ elevation [41]. Applegate River. Locality in species accounts refers to an area near Ruch [46].

Ashland. The southernmost city of Jackson County; elevation, 1,951 feet $(594.6 \mathrm{~m})$ [44].

Baldy or Mount Baldy. A rounded mountain 3 miles $(4.8 \mathrm{~km})$ northeast of Phoenix in the western Cascade Mountains; elevation, 3,844 feet $(1,171.6 \mathrm{~m})$ [34].

Bear Creek. Primary drainage of Bear Creek Valley (from near Ashland to the backwaters of Gold Ray Dam) [42].

Big Butte Creek. A major tributary of the Rogue River beginning in the Cascade Mountains at about 3,000 feet $(914.4 \mathrm{~m})$ elevation and flowing into the Rogue River near 1,500 feet, 5 miles $(8 \mathrm{~km})$ east of Trail [5].

Central Point. A town 1 mile $(1.6 \mathrm{~km})$ northwest of Medford; elevation, 1,272 feet $(387.7 \mathrm{~m})$ [26].

Coleman Creek. A tributary of Bear Creek beginning 6 miles $(9.6 \mathrm{~km})$ north of Phoenix at about 5,185 feet $(1,580.4 \mathrm{~m})$ elevation near the foot of Anderson Butte, Siskiyou Mountains [38]. 
Eagle Point. A town north-northeast of Medford on Little Butte Creek; elevation, 1,365 feet $(416 \mathrm{~m})$ [9].

Fish Lake. A reservoir in the Cascade Mountains in extreme eastcentral Jackson County; elevation, 4,642 feet $(1,414.9 \mathrm{~m})$ [24].

Gume Ponds. Area of diked ponds and marsh edge about 4 miles $(6.4 \mathrm{~km})$ north of Medford and 1 mile $(1.6 \mathrm{~km})$ south-southwest of White City; elevation, about 1,280 feet $(390.1 \mathrm{~m})$ [20]. This is the Ken Denman Game Management Area administered by the Oregon State Game Commission.

Gardner Reservoir. A reservoir in the Cascade Mountains near the headwaters of Yankee Creek about 10 miles $(16.1 \mathrm{~km})$ east of Medford; elevation, 2,760 feet $(84.2 \mathrm{~m})$ [23].

Goldhill. A town on the Rogue River about 8 miles $(12.9 \mathrm{~km})$ northnorthwest of Medford; elevation, 1,085 feet (330.7 m) [16].

Gold Ray Dam. Power dam on the Rogue River about 6 miles $(9.7 \mathrm{~km})$ north-northwest of Medford; elevation, 1,168 feet (356 m) [12].

Hoover's Lakes. A series of five small reservoirs about 5 miles $(8 \mathrm{~km})$ northeast of Medford and 2 miles $(3.2 \mathrm{~km})$ southeast of White City; elevation, 1,326 feet (404.1 m) [19].

Howard Prairie Reservoir. Largest reservoir of Jackson County with an area of about 6 square miles (9.7 square $\mathrm{km}$ ), in the Cascade Mountains about 14 miles $(22.5 \mathrm{~km})$ east of Ashland; elevation, 4,530 feet $(1,380.7 \mathrm{~m})[40]$.

Hyatt (Prairie) Reservoir. Cascade Mountain reservoir 11 miles east of Ashland; elevation, 5,016 feet $(1,528.8 \mathrm{~m})$ [45].

Jacksonville. A town 2 miles $(3.2 \mathrm{~km})$ west of Medford; elevation, 1,568 feet $(477.9 \mathrm{~m})[32]$.

Johns Peak. Three miles $(4.8 \mathrm{~km})$ northwest of Medford in the Klamath-Siskiyou Mountains; elevation, 2,807 feet ( $855.5 \mathrm{~m}$ ) [28].

Kelly Slough. Backwater on the Rogue River formed by Gold Ray Dam.

Ken Denman Game Management Area. See Game Ponds.

Larson Creek. A tributary of Bear Creek beginning about $1 / 2$ mile $(0.8 \mathrm{~km})$ north of Baldy at 3,400 feet $(1,036.3 \mathrm{~m})$ elevation. Records in the species accounts refer to the area along the Creek 3 miles $(4.8 \mathrm{~km})$ east of Medford at an elevation of about 1,800 feet $(548.6 \mathrm{~m})$ [31].

Little Butte Creek. A major tributary of the Rogue River beginning over 30 miles $(48.3 \mathrm{~km})$ east of its junction; elevation at its headwaters about 4,600 feet $(1,402 \mathrm{~m})$ [18].

Lower Rogue River Valley. Rogue River Valley downstream from Shady Cove to Jackson-Josephine County boundary. 
Lower Table Rock. A mesa (about 101 hectares) adjacent to the Rogue River occupying Sam's Valley; elevation, 3,008 feet $(916.8 \mathrm{~m})$ [13].

Medford. Largest city in Jackson County located in the south-central portion of the county in Bear Creek Valley; elevation, 1,382 feet $(421.2 \mathrm{~m})[30]$.

Medford Municipal Airport. One and one-half miles $(2.4 \mathrm{~km})$ north of Medford; elevation, 1,318 feet $(401.7 \mathrm{~m})$ [25].

Mount Ashland. Highest point in the Siskiyou Mountains about 6 miles $(9.7 \mathrm{~km})$ south of Ashland; elevation, 7,533 feet $(2,296 \mathrm{~m})$ [49].

Mount McLoughlin. Highest point in the county located in the High Cascades in the extreme east-central part of the county; elevation, 9,495 feet $(2,894.1 \mathrm{~m})$ [15].

Old Military Bridge. Remains of a bridge once crossing the Rogue River at the mouth of Little Butte Creek; elevation about 1,200 feet $(365.7 \mathrm{~m})$ [14].

Oregon Switzerland. Forested area in the Cascade Mountains 3 miles $(4.8 \mathrm{~km})$ east of Medford and about 1 mile $(1.6 \mathrm{~km})$ southeast of Roxy Ann Peak; elevation about 2,600 feet (792.4 m) [29].

Phoenix. A town 3 miles $(4.8 \mathrm{~km})$ southeast of Medford in Bear Creek Valley; elevation, 1,543 feet $(470.3 \mathrm{~m})$ [36].

Pompadour Bluff. A rock scarp 2 miles $(3.2 \mathrm{~km}$ ) east of Phoenix in the Cascade foothills; elevation, 2,004 feet $(610.8 \mathrm{~m})$ [43].

Prospect. A town near the Rogue River in the Cascade Mountains; elevation, 2,598 feet $(791.8 \mathrm{~m})$ [2].

Rogue River. The major drainage of Jackson County, beginning in the extreme northern part of the county (its headwaters are at the northern boundary of Crater Lake National Park in Klamath County) and flowing southwest to about the west-central portion of the county. Its upstream elevation is about 3,400 feet $(1,036.3 \mathrm{~m})$; its downstream terminus, at the Jackson-Josephine County line, is about 1,000 feet $(304.8 \mathrm{~m})$ elevation [3].

Rogue River. A town 12 miles $(19.3 \mathrm{~m})$ northwest of Medford on the Rogue River, in the west-central part of the county; elevation, 1,001 feet $(305.1 \mathrm{~m})$ [11].

Roxy Ann Peak. A 3,571-foot $(1,088.4 \mathrm{~m}) \mathrm{knob}$ of the Cascade foothills 2 miles $(3.2 \mathrm{~km})$ northeast of Medford [27].

Ruch. A town near the Applegate River about 7 miles $(11.3 \mathrm{~km}$ ) southwest of Medford; elevation, 1,527 feet $(465.4 \mathrm{~m})$ [37].

Sam's Valley. A lowland area north of the Rogue River near Gold Ray Dam, divided by Lower and Upper Table Rocks; considered part of the Lower Rogue River Valley. Elevations range between about $1,200(365.7)$ to 1,300 feet $(396.2 \mathrm{~m})$ [7]. 
Shady Cove. A town on the Rogue River about 17 miles $(27.4 \mathrm{~km})$ north of Medford; elevation, 1,399 feet $(426.4 \mathrm{~m})$ [6].

Talent. A town 5 miles $(8 \mathrm{~km})$ south of Medford in Bear Creek Valley; elevation, 1,635 feet $(498.3 \mathrm{~m})$ [39].

Tombstone. Rocks 1 mile $(1.6 \mathrm{~km})$ south of Baldy and abour 5 miles $(8 \mathrm{~km})$ north-north-west of Ashland; elevation, 3,227 feet $(983.6 \mathrm{~m})$ [35].

Trail. A town on the Rogue River 20 miles $(32.2 \mathrm{~km})$ north of Medford; elevation, 1,433 feet $(436.7 \mathrm{~m})$ [4].

Union Creek. A town in the Cascade Mountains near the Rogue River in northern Jackson County; elevation, 3,332 feet $(1,015.6$ m) [1].

Upper Rogue River Valley. Rogue River Valley upstream from Shady Cove to near Union Creek.

Upper Table Rock. A mesa adjacent to the Rogue River occupying Sam's Valley, with an area of about 500 acres (202.3 hectares); elevation, 2,068 feet $(630.3 \mathrm{~m})$ [8].

Voorhies Crossing. An area of Bear Creek named for its proximity to the railroad crossing at Voorhies, located about $11 / 2$ miles $(2.4 \mathrm{~km})$ south of Medford; elevation, 1,440 feet $(438.9 \mathrm{~m})$ [33].

Wagner Butte. A peak in the northern part of the Siskiyou Mountains 4 miles $(6.4 \mathrm{~km})$ southwest of Ashland; elevation, 7,140 feet $(2,176.2$ m) [48].

White City. A town 7 miles $(11.3 \mathrm{~km})$ north of Medford; elevation, 1,327 feet $(404.4 \mathrm{~m})$ [21].

Willow Creek Reservoir. A reservoir in the Cascade Mountains in east-central Jackson County; elevation, 3,014 feet (918.6 m) [10]. 


\section{AVIAN COMMUNITIES}

Of the 259 species of birds that have been recorded in Jackson County, 136 are represented by specimens and 14 species are documented by photographic records. There are 109 species included on the basis of reliable sight records. Four species formerly occurring in the county have been extirpated. Thus, I recognize a total of 255 species as definitely occurring in Jackson County.

Of this total 133 definitely breed in the county, 15 probably breed, and 13 species possibly breed. (See Plan of the Species Accounts for definitions of probably and possibly.) Thirty species are winter residents or regular winter visitors and 52 species are predominantly transient. Another 12 are considered accidentals or stragglers, mostly from east of the Cascade Mountains or from California. Three of the four extirpated species, Chukar, ${ }^{1}$ Grey Partridge, and Bobwhite, were introduced and were unsuccessful in the county. The fourth species, Nuttall's Woodpecker, probably once bred in the Siskiyou Mountains of Jackson County.

Ten species have recently extended their breeding range into Jackson County or have increased in abundance as breeding species or as regular summer visitors.

$\begin{array}{ll}\text { Green Heron } & \text { Long-billed Marsh Wren } \\ \text { Anna's Hummingbird } & \text { Blue-gray Gnatcatcher } \\ \text { Allen's Hummingbird } & \text { Tricolored Blackbird } \\ \text { Black Phoebe } & \text { Yellow-headed Blackbird } \\ \text { Bank Swallow } & \text { Black-throated Sparrow }\end{array}$

All of the 10 species definitely breed except the wren and blackbird that probably breed, and the two hummingbirds and the sparrow that are considered summer visitors.

Most of the Jackson County avifauna is similar to that of the Cascade Mountains and western valleys of Oregon. There are several subspecies restricted in Oregon to the geographic area covered in this paper (see Gabrielson and Jewett 1940). Lack of data at the subspecific level, however, precludes discussion of subspecies in this paper.

\footnotetext{
1 See Species Accounts for scientific names.
} 
There are six full species in Oregon that are primarily restricted to Jackson County although they occur in certain parts of California, Nevada, and other States to the south and east. The Tricolored Blackbird breeds in eastern Oregon. The following species are known to breed in the Lower Rogue River Valley:

$\begin{array}{ll}\text { Acorn Woodpecker } & \text { Blue-gray Gnatcatcher } \\ \text { Black Phoebe } & \text { Tricolored Blackbird } \\ \text { Plain Titmouse } & \text { Brown Towhee }\end{array}$

The Acorn Woodpecker, Plain Titmouse, and Brown Towhee were apparently well established as breeding species by the time Gabrielson and Jewett (1940) completed their field work in southern Oregon. The remaining three species have become breeding birds in the study area only recently.

Gabrielson and Jewett (1940:605) placed the Black Phoebe on their hypothetical list on the basis of two early records from the Umpqua Valley and from Salem. Breeding was confirmed in Jackson County in 1953 (Richardson and Sturges 1964). Grinnell and Miller (1944:253) do not list Siskiyou County, California, immediately to the south of Jackson County, as a breeding locality, although they cite breeding records from counties to the south and west of Siskiyou County as extreme northern breeding locations. It seems probable that the Black Phoebe first entered Jackson County via the Applegate River or Siskiyou Pass southeast of Ashland, both of which offer relatively low access over the Siskiyou Mountains.

Breeding was attempted by a pair of Blue-gray Gnatcatchers on Roxy Ann in 1963, and young were successfully fledged the following year (Richardson and Sturges 1964). At least one pair of this species has bred on Roxy Ann annually since then; six pairs and one nest were found in 1971. This species was reported breeding in Siskiyou County, California (at Hornbrook and Yreka), as early as 1870 (Grinnell and Miller 1944:368).

Tricolored Blackbirds have been known to breed in Klamath County, Oregon, since 1933 (Gabrielson and Jewett 1940). The species was first observed in Jackson County during the summer of 1956 and breeding was verified in 1960 (Richardson 1961).

Within Jackson County, certain breeding species are restricted to major plant communities. 
Species restricted to the Chaparral-Oak Community, Lower Rogue Valley are the following:

California Quail
Ring-necked Pheasant
Virginia Rail
Sora
Poor-will
*Acorn Woodpecker
Western Kingbird
Black Phoebe
*Plain Titmouse
Wren-tit
Black-chinned Sparrow

Long-billed Marsh Wren

${ }^{*}$ Rock Wren

Blue-gray Gnatcatcher

Yellow-breasted Chat

Yellow-headed Blackbird

Tricolored Blackbird

*Northern Oriole

*Lazuli Bunting

Lesser Goldfinch

Brown Towhee

Lark Sparrow

The Sora and Black-chinned Sparrow possibly breed in the county, and the Long-billed Marsh Wren probably breeds there. All other pecies have been confirmed to breed in the county.

Five of the above species (des gnated *) also breed in the ChaparralOak Community of extreme southeastern Jackson County. This part of the county differs from the Lower Rogue River and Bear Creek valleys in climate, elevation, and somewhat by dominant vegetation. Average elevations are $610 \mathrm{~m}$ for the valley area and $914 \mathrm{~m}$ for the southeastern part of the county. Climatic conditions are not specifically known for the southeastern part of the county, but mean temperature is undoubtedly lower than in Medford and precipitation is probably greater with more snow. Dominant plants in the southeast include Quercus spp., Pinus ponderosa, and Ceonothus spp.

Species restricted to Mixed Conifer Forest (Pinus dominated) are: White-headed Woodpecker, Pygmy Nuthatch, and Green-tailed Towhee.

Species restricted to Mixed Conifer Forest (non-Pinus) are: Pygmy Owl, Vaux's Swift, Winter Wren, and MacGillivray's Warbler.

Species restricted to 'True Fir Forest are: Williamson's Sapsucker, Black-backed Three-toed Woodpecker, Olive-sided Flycatcher, Gray Jay, Hermit Warbler, and Cassin's Finch.

Species restricted to Timberline Forest are: Northern Three-toed Woodpecker and Clark's Nutcracker.

All avian species found in the Siskiyou Mountains are found in the Cascade Mountains. There are, however, seven species found in the Cascade Mountains that are not found in the Siskiyou Mountains. Gabrielson (1931:110) also mentioned similar differences. The differences in the avifauna between the Siskiyou and Cascade mountains are not readily apparent. Waring (1969) considers the Siskiyou Mountains to be poorly represented by mesophytes and Franklin and Dyrness 
(1973) consider the dominant vegetation of the eastern Siskiyou and Cascade mountains to differ from that of the western Siskiyou Mountains. Information on the avifauna of the Siskiyou Mountains is not sufficient to compare species composition between the eastern and western Siskiyou Mountains. Further study in all disciplines of vertebrate zoology (S. Cross, personal communication), botany (J. F Franklin, personal communication), and geology (W. Purdom, personal communication) are required to evaluate the avian ecology in the Siskiyou Mountains.

The absence of seven species in the Siskiyou Mountains of Jackson County may be attributed to the absence of certain habitats. For example, no sizeable bodies of water exist in the drier Siskiyou Mountains which may account for the absence of Bank Swallows, Purple Martins, and Lincoln's Sparrows. Also, the Siskiyou Mountains have received little ornithological attention, and some species may have been simply overlooked. Listed below are seven species that breed in the Cascade Mountains with suggested reasons for the species absence in the Siskiyou Mountains.

Bank Swallow.-This swallow requires specific nesting habitat that is lacking in the Siskiyou Mountains.

Purple Martin.-This species is possibly not found in the Siskiyou Mountains because of little habitat near reservoirs where it has bred in the Cascade Mountains.

Black-billed Magpie.-Stragglers apparently originate from Klamath County moving over the Cascade Mountains.

Pygmy Nuthatch.-The distribution of this species is puzzling. Pinus ponderosa stands and Mixed Conifer Forest where Pinus is dominant cover much of the Siskiyou Mountains although there are no records of this nuthatch in Jackson County except from the Cascade Mountains. Discontinuous distribution of the species from California begins in the eastern Cascade Mountains.

Canon Wren.-Grinnell and Miller (1944:342) do not record this wren in the California Siskiyou Mountains, although it seems likely that it may breed in the canyons of the drier slopes of the eastern Siskiyou Mountains.

Red Crossbill.-There are so few records of this species in the county that its rarity is magnified by lack of man-hours spent in the Siskiyou Mountains; it is likely that the species has been overlooked.

Lincoln's Sparrow.-Lack of wet meadow-type habitat in the Siskiyou Mountains probably prevents this species from breeding there. 


\section{PLAN OF THE SPECIES ACCOUNTS}

The sequence and names of genera and species follow the A.O.U. Check-list of North American Birds (1957) and the Thirty-second Supplement of the Check-list (American Ornithologists' Union 1973). Each species is introduced by its scientific name, followed by the common name. At the beginning of each species account I have listed recent specimens from Jackson County under the heading, "Specimen(s)." Specimens reported in recent literature are cited within the text of the species account. Photographs are cited under the heading of "Photograph(s)" to document the occurrence of certain species. Data listed under "Photograph(s)" and/or "Specimen(s)" include location, sex (specimens only), date, and if photographs exist, initials of the photographer. Important literature is cited and records outside Jackson County, especially from west of the Cascade Mountains in Oregon, are mentioned. References to Christmas Bird Counts (abbreviated CBCs) are made in some of the species accounts.

Terms indicating frequency of occurrence of species are often vague or misleading. In an effort to standardize terminology and reduce subjectivity, I have adopted the system developed by Arbib (1957:63$64)$.

In all instances of abundance I have chosen to use the nonbreeding abundance scale (Arbib 1957:63-64) due to the lack of sufficient quantitative data on breeding bird numbers; the abundance scale as used here thus refers to both breeding and nonbreeding species.

\section{Abundance Scale}

Abundant. Occurring in such numbers that a competent observer, in a single day, at the appropriate time and place (=habitat), might see or hear more than 500 individuals.

Very common. 101 to 500 individuals in a single day.

Common. 26 to 100 in a single day.

Fairly common. 6 to 25 in a single day.

Uncommon. One to five in a single day and no more than 25 per season.

Rare. One to five in a single day and no more than five per season.

Very Rare. No more than one per day and no more than one per season. 


\section{Frequency Scale}

Regular. Recorded every year.

Irregular. Recorded less than once every year, but no less than once in $5 \mathrm{yr}$, on the average.

Occasional. Recorded less than once in $5 \mathrm{yr}$, but no less ihan once in $10 \mathrm{yr}$, on the average.

Sporadic. Recorded less than once in $10 \mathrm{yr}$, but no less than once in $20 \mathrm{yr}$, on the average.

Casual. Recorded less than once in $20 \mathrm{yr}$, on the average.

Accidental. Recorded, but because of the species normal range it is not expected to occur again. This term replaces the term "Exotic" proposed in Arbib (1957:63-64).

\section{Seasonal Occurrence}

Resident. Breeding species, summer resident, winter resident, or permanent resident.

Visitant (=visitor). A nonbreeding species which occurs either as a summer or a winter visitor.

I apply the term migrant to those species that occur only during migration. Records of migrants, and summer or winter residents are listed with dates of arrival and departure where possible.

Species that are considered definitely breeding are stated simply as breeding species or summer residents. Where the breeding status of certain species is in doubt I have used the terms "probably" or "possibly" breeds. The term "probably" refers to species that aro regular summer residents and are of ten observed singing, but no nest, eggs, young, or food carrying by adults has been observed. "Possibly" breeds refers to summer residents that, al though within their normal breeding range and habitat, have been observed infrequently and may breed in small numbers; no breeding behavior has been observed. 


\section{SPECIES ACCOUNT}

Gavia immer. Common Loon.

The Common Loon is a rare and irregular visitor. There are sight records of single individuals from the game ponds, January 8, 1965, May 3, 1966, and November 15, 1965, and at Agate Reservoir, May 16, 1971. Three were observed at Willow Creek Reservoir on April 12, 1957.

Podiceps grisegena. Red-necked Grebe.

This grebe is an irregular migrant, occasionally breeding. It is uncommon on the Rogue River below Shady Cove and at Hoover's Lakes from late April to May and late August to November during migration. Three young with two adults were observed at Howard Prairie Reservoir on June 22, 1969, the only breeding record. Kebbe (1958b) records this grebe breeding on Upper Klamath Lake, Klamath County. An individual observed at Hoover's Lakes on January 12, 1959 , is the only winter record.

Podiceps auritus. Horned Grebe.

Specimen: Prospect, sex not indicated, October 31, 1935. This species is a spring migrant occurring occasionally at Gardner Reservoir and the Game Ponds during April. One was observed north of Medford on January 10, 1960.

Podiceps nigricollis. Eared Grebe.

The Eared Grebe is an uncommon irregular migrant and winter resident on the Rogue River, Hoover's Lakes, and Lower Rogue River Valley ponds. Earliest, October 5, Hoover's Lakes; latest, April 25, north of Medford. Small numbers, usually single individuals, are observed north of Medford during winter.

Aechmophorus occidentalis. Western Grebe.

This large grebe is a regular uncommon spring and fall migrant and an irregular summer and winter visitor. One was observed at the Game Ponds on July 13, 1952. Single individuals are occasionally recorded on the Medford CBCs. Most frequently observed at the Game Ponds and Hoover's Lakes, this species may be expected at almost any Lower Rogue River Valley pond.

Podilymbus podiceps. Pied-billed Grebe.

Specimen: $3.2 \mathrm{~km} \mathrm{~W}$ Prospect, male, November 7, 1935. This small grebe has been found on many shallow ponds and reservoirs, Bear 
Creek, and the Rogue River and may be expected throughout most of Jackson County. Although considered a fairly common resident, breeding has not been verified.

Pelecanus erythrorhynchos. White Pelican.

There are three records of this species in Jackson County. One was at the Game Ponds, August 16 through August. 18, 1961, and one, possibly the same individual, was observed at Hoover's Lakes, August 18,1961 . Two were seen at the Game Ponds in October 1964. The species is considered a rare straggler in the area.

Phalacrocorax auritus. Double-crested Cormorant.

Specimen: Prospect, two males, April 8, 1935. The Double-crested Cormorant formerly nested at Hyatt Lake, but presently it is considered a rare irregular fall migrant. Individuals have been seen at Gold Ray and the Game Ponds in September.

Ardea herodias. Great Blue Heron.

This large heron is a common resident that may be found throughout the county near water. Solitary nesting pairs are most generally reported although eight occupied nests were observed at the Gold Ray-Kelly Slough February 20, 1963, and January 28, 1964.

Butorides virescens. Green Heron.

The Green Heron is an uncommon regular migrant and summer resident of the Chaparral-Oak Community of the Lower Rogue River Valley. Earliest, April 10, Phoenix; latest, late August, Medford. Breeding was not confirmed until 1970 when two young were fledged from an oak tree nest in residential Medford on August 24. A pair abandoned a nest containing two eggs at the same tree in 1971 after Aphelocoma coerulescens (Scrub Jays) reportedly ate the eggs. The pair renested nearby the same year, but success was not determined. Jewett (1945) first recorded this species breeding in northwestern Oregon and Evenden (1947) cites several breeding pairs near Corvallis.

Casmerodius albus. Common Egret.

This heron is an irregular visitor throughout the Lower Rogue River Valley. The species has been observed in January to March, June, July, October, and December. Single birds have been reported on 2 of 13 CBCs at Medford.

Egretta thula. Snowy Egret.

The Snowy Egret is known to have occurred in Jackson County twice in spring at Hoover's Lakes, April 25, 1960, and near Ashland, April 6, 1963.

Nycticorax nycticorax. Black-crowned Night Heron.

Specimen: $11.3 \mathrm{~km}$ SW Prospect, female, 1958. This heron is a common resident throughout the Lower Rogue River Valley in the 
Chaparral-Oak Community. It breeds in small rookeries (10-20 nests), which change location north of Medford each year. Winter roosts of 5 to 10 birds have been found in Medford, Central Point, and Phoenix.

Ixobrychus exilis. Least Bittern.

Specimen: $8.0 \mathrm{~km}$ SW Prospect, sex ?, August 10, 1959. The only other record of this species in Jackson County is the sighting of an adult at Hoover's Lakes on July 29, 1961. Gabrielson and Jewett (1940) list it as a breeding species in neighboring Klamath County.

Botaurus lentiginosus. American Bittern.

Three recent records exist for this bittern. One individual was observed for 3 wk during September 1963, one was seen near Old Military Bridge on May 30, 1963, and one was at Hoover's Lakes on May 16, 1971. Gabrielson (1931) saw one at the headwaters of Big Butte Creek on September 20, 1927. Gabrielson and Jewett (1940) consider this species as an uncommon resident west of the Cascades, including Jackson County, but on the basis of available records it should be considered a rare migrant.

Olor columbianus. Whistling Swan.

This species is an uncommon to common regular migrant and winter resident on large ponds and reservoirs throughout the Lower Rogue River and Bear Creek valleys from November through March. It is regularly recorded on CBC's in numbers from 5 to 24 individuals.

Branta canadensis. Canada Goose.

Specimen: $12.9 \mathrm{~km}$ SW Prospect, male, October 30, 1958. Photograph: Hyatt Reservoir, pair with young, June 1964 (JH). This goose is a very common to uncommon migrant and winter resident that may be found on most waterbodies throughout the Lower Rogue River Valley. It nests at Howard Prairie and Hyatt reservoirs. The only summer record for the Lower Rogue River Valley is one observed at Hoover's I,akes on July 28, 1961.

Branta nigricans. Black Brant.

Photograph: Game Ponds, March $1963(\mathrm{JH})$. The only record is of an adult photographed at the Game Ponds on March 14, 1963, following a snowstorm (Browning, 1966b). Gabrielson and Jewett (1940) have records of this straggler from the coast for Yamhill, Linn, Klamath, and Douglas counties. Kebbe (1958a) reports this species as occurring in the Klamath Basin but lists no specific records except for one bird shot in Warner Valley $64.4 \mathrm{~km}$ east of Lakeview in November 1950 .

Anser albifrons. White-fronted Goose.

There are several sight records of this rare migrant and winter visitor in the Lower Rogue River Valley during January, April, May, October, and December. 
Chen caerulescens. Snow Goose.

The Snow Goose is a rare winter visitor and spring migrant and records exist from various ponds north of Medford. One bird spent the winter of 1959-60 with a flock of domestic geese at Hoover's Lakes.

Anas platyrhynchos. Mallard.

Specimen: Ashland, female, May 14, 1971. This duck is a very common to common permanent resident increasing in number during winter and migration. It may be found throughout most of Jackson County.

Anas strepera. Gadwall.

The Gadwall is a fairly common regular winter resident and spring migrant throughout the southern portion of the county below $762 \mathrm{~m}$. Earliest, November 22, Game Ponds; latest, March 13, Medford.

Anas acuta. Pintail.

The Pintail is a common migrant and winter resident at Hyatt, Howard Prairie, and Gardner reservoirs, Hoover's Lakes, Game Ponds, and at scattered small ponds throughout the Lower Rogue River Valley. This species has been recorded very regularly on the CBCs.

Anas crecca. Green-winged Teal.

This species is a common winter resident and migrant and uncommon summer resident that possibly breeds at the Game Ponds.

Anas discors. Blue-winged Teal.

Specimen: $12.9 \mathrm{~km} \mathrm{SW}$ Prospect, male, June 20, 1945. This teal is an uncommon spring migrant and occasional summer resident of the Lower Rogue River Valley where shallow water and cattail cover are found. The earliest observation is April 22, Game Ponds, the latest, June 25, Hoover's Lakes. There are several "breeding" records of this teal from ponds north of Medford. As noted by McAllister (1949), these records may be of Anas cyanoptera, the Cinnamon Teal.

Anas cyanoptera. Cinnamon Teal.

The Cinnamon Teal is a fairly common migrant and rare winter visitor, most frequently seen on ponds north of Medford. It arrives in February and increases in numbers during March. Pairs have been seen as late as June on the Game Ponds and on Bear Creek near Phoenix.

Anas penelope. European Wigeon.

This species is a very rare straggler on the basis of three sight records of males. One was seen by two observers at Willow Springs Reservoir on March 3, 1958; and one each at Ashland on January 8, 1962, and on December 25, 1961, by several observers. Gabrielson and Jewett (1940) discuss several sight records and list five winter specimens from Oregon. 
Anas americana. American Wigeon.

This duck is a common winter resident and irregular spring and summer visitor in the Lower Rogue River and Bear Creek valleys. This species has been recorded on 12 of 13 Medford CBCs with an average of about 30 birds per count.

Anas clypeata. Shoveler.

The Shoveler is a fairly common migrant and winter visitor. It arrives about November and leaves about March and may be expected throughout the county.

Aix sponsa. Wood Duck.

Specimens: $12.9 \mathrm{~km}$ SW Prospect, female, October 9, $1951 ; 17.7 \mathrm{~km}$ SW Prospect, male, date?. The Wood Duck is a fairly common resident in the Lower Rogue River and Bear Creek valleys. Small numbers have also been observed on Gardner Reservoir. It breeds throughout its range; many breed on a small pond in Ashland's city park.

Aythya americana. Redhead.

The Redhead winters in small numbers and has been recorded from ponds north of Medford and Gardner Reservoir. This species may be expected on other bodies of water in Jackson County.

Aythya collaris. Ring-necked Duck.

Specimen: $3.2 \mathrm{~km}$ W Prospect, female, November 5, 1935. This duck is a common winter resident throughout Jackson County. Earliest, September, Rogue River Valley; latest, June 27, 1964, Hoover's Lakes.

Aythya valisineria. Canvasback.

The Canvasback is an uncommon winter resident recorded in the same areas as the Redhead, but in slightly greater numbers.

Aythya affinis. Lesser Scaup.

This diving duck is a common migrant and winter resident at Gardner Reservoir, ponds north of Medford, and Bear Creek Valley. This species is most frequently observed at Hoover's Lakes and the Game Ponds. It is regularly recorded on Medford CBCs; most birds arrive about September and depart by April.

Bucephala clangula. Common Goldeneye.

This duck is a rare winter resident and visitor and only three records are known from Jackson County. One bird wintered at the Game Ponds during 1961; one was observed at Willow Creek Reservoir on December 28, 1962, and two were seen on Howard Prairie Reservoir on January 14, 1962.

Bucephala islandica. Barrow's Goldeneye.

This goldeneye is a rare and irregular winter visitor. Twelve were seen at Hoover's Lakes during January and February 1966, and two 
females were there in 1969 (month ?). Gabrielson and Jewett (1940) report that it breeds regularly in Cascade Mountain lakes.

Bucephala albeola. Bufflehead.

Specimen: $3.2 \mathrm{~km} \mathrm{~W}$ Prospect, female, November 5, 1935. The Bufflehead is an uncommon and irregular winter resident. Gabrielson and Jewett (1940) give September 20 (Lake County) for their earliest Oregon date and May 15 (Tillamook County) for their latest date. Buffleheads have been recorded between those dates at Gardner Reservoir, Hoover's Lakes, and at the Game Ponds. They should also be expected at Willow Creek, Hyatt, and Howard Prairie reservoirs, and other mountain bodies of water.

Oxyura jamaicensis. Ruddy Duck.

Specimen: Ashland, male, April 23, 1960. The Ruddy Duck is a common winter resident from November to March, occurring wherever there is open water. During December at least one individual may be found on almost every body of water north of Medford as far as the Rogue River. Of 13 Medford CBCs, this species has been recorded on 10 at an average of 49 individuals per count.

Lophodytes cucullatus. Hooded Merganser.

This species is an uncommon late winter resident and spring migrant. Latest, April 5, Shady Cove. This merganser probably occurs throughout Jackson County. A record number of 20 was reported on the 1965 Medford CBCs.

Mergus merganser. Common Merganser.

Specimens: Three, $12.9 \mathrm{~km}$ SW Prospect, two females, May 27, 1935, one male, May 28, 1935. This duck is a common resident on the Rogue River below Prospect; it is less common on the Lower Rogue River Valley ponds in winter.

Mergus serrator. Red-breasted Merganser.

This merganser is a rare winter visitor. Two females and a male were observed on the Game Ponds on November 22, 1964, where one female and the male remained until mid-March 1965. Gabrielson and Jewett (1940) consider the species a casual inland winter visitor on the basis of late nineteenth century records.

Cathartes aura. Turkey Vulture.

Specimen: Ashland, male, April 15, 1959. The Turkey Vulture is a common summer resident throughout Jackson County, except in the Timberline Forest. Earliest, February 15, Medford; latest, September 30 , Medford. It breeds in valley foothills and mountains.

Accipiter gentilis. Goshawk.

Specimens: Two, $12.9 \mathrm{~km}$ SW Prospect, male, December 18, 1944, and male, April 26, 1944; and two from Ashland, sex ?, February 2, 
1963 , and female, October 20,1961 . The Goshawk is a rare permanent resident probably throughout the forested areas of Jackson County, and it is an occasional visitor to the Chaparral-Oak Community during winter. There are several winter records of single individuals from Talent, Ashland, Medford, Larson Creek, and Shady Cove.

Accipiter striatus. Sharp-shinned Hawk.

Specimens: Five, both sexes, $12.9 \mathrm{~km}$ SW Prospect, March 24, 1949, October 25, 1958, November 11, 1958, January 22, 1937, and October 12, 1946; and one near 'Talent, sex?, June 10, 1969. Uncommon resident increasing in numbers in the Chaparral-Oak Community, especially along streams during winter. This species probably occurs throughout Jackson County in forested areas.

Accipiter cooperii. Cooper's Hawk.

Specimens: Three, $17.7 \mathrm{~km}$ SW Prospect, male, November 9, 1948, male, November 17, 1952, and female, March 6, 1937; Medford, female, March 25, 1971. This hawk is an uncommon resident that increases in numbers in the Chaparral-Oak Community, especially along streams, in winter. The species is slightly more common, or at least more conspicuous, than the Sharp-shinned Hawk during winter. The Cooper's Hawk has been observed at Roxy Ann Peak, Pompadour Bluffs, Upper Table Rock, Larson Creek, Coleman Creek, Tombstone, and in the Cascades along Dead Indian Road.

Buteo jamaicensis. Red-tailed Hawk.

Specimens: Ashland, female, October 30, 1961; Medford, male, no date. This soaring hawk is a common permanent resident occurring at most elevations throughout Jackson County. It is less common in Lower Rogue River and Bear Creek valleys during summer.

Buteo swainsoni. Swainson's Hawk.

The Swainson's Hawk is a rare straggler west of the Cascades. Three authentic sight records have been made by competent observers: One at Medford, September 8, 1958; one observed twice in the foothills east of Ashland during August 1963; and one between Howard Prairie and Hyatt reservoirs, May 11, 1961. This Buteo has been reported three times within recent years on Medford CBCs. Although these winter records have been published (Aud. Field Notes $1965: 320$ ), none of the observers reporting these birds were familiar with the species. Until more reliable data can be collected on winter occurrences, Swainson's Hawk should be considered only as a rare migrant and summer visitor.

Buteo lagopus. Rough-legged Hawk.

This species is a rare winter straggler. One was observed at Medford on November 24, 1958; two were seen north of Medford on December 30, 1960; and one wintered, 1960-61, at White City. 
Single birds have been recorded in the Lower Rogue River Valley during the winter of 1969,1970 , and 1971. An individual was shot near Medford, February 22, 1930 (Gabrielson 1931).

Buteo regalis. Ferruginous Hawk.

This hawk is a rare straggler occurring on Mount Ashland, Anderson Creek $(457 \mathrm{~m})$, and north of Medford near White City, on September 1, 1954, September 20, 1958, and December 27, 1957, respectively. One individual was observed on each occasion.

Aquila chrysaetos. Golden Eagle.

Specimen: Ashland, female, November 3, 1970. Probably a permanent resident. There are records of this eagle from Ashland, Baldy, Upper Table Rock, Johns Peak, Roxy Ann Peak, Pompadour Bluffs, and various locations in the Lower Rogue River and Bear Creek valleys for the months of March, August, November, and December. Gabrielson and Jewett (1940) mention one sight record from Goldhill.

Haliacetus leucocephalus. Bald Eagle.

Photograph: Sterling Creek (near Jacksonville), adult, February $1964(\mathrm{JH})$. The Bald Eagle is probably a permanent resident in the High Cascades and Siskiyou mountains. A pair was periodically observed at a nest near Hyatt Lake during the spring of 1970 , but the actual breeding status of this pair is unknown. This species has been seen several times at Gardner, Hyatt, Howard Prairie, and Willow Creek reservoirs during summer and winter months. There are several records from along the Rogue River and Larson Creek.

Circus cyaneus. Marsh Hawk.

The Marsh Hawk is an uncommon permanent resident throughout the Lower Rogue River and Bear Creek valleys. This hawk is often observed north of Medford to White City. An average of three individuals are reported annually on the CBCs.

Pandion haliaetus. Osprey.

The Osprey is an uncommon permanent resident in the Lower Rogue River Valley. Gabrielson and Jewett (1940) stated that several pairs were nesting along the Rogue River, but populations have been diminishing throughout its Oregon range. Until recently the only known nest in Jackson County was near Shady Cove on the Rogue River, which was occupied annually from 1948 to 1964 . Nesting at this site was not observed again until 1970 and 1971. Nesting pairs were observed near Gold Ray Dam and at Hyatt Reservoir in 1970 and 1971. One individual was recorded from Little Butte Creek near Eagle Point on November 22, 1964.

Falco mexicanus. Prairie Falcon.

This species is an uncommon irregular visitor. The Prairie Falcon has been reported at Roxy Ann Peak, Ashland, Phoenix, and White 
City in December to May. Stevenson and Fitch (1933) report a sight record of an individual $9.7 \mathrm{~km}$ south of Medford.

Falco peregrinus. Peregrine Falcon.

The Peregrine Falcon is a rare migrant along the Lower Rogue River. There are two records from Medford, January 7, and February $15,1958$.

Falco columbarius. Pigeon Hawk.

Specimen: Two males, $12.9 \mathrm{~km} \mathrm{SW}$ Prospect, December 7, 1947, and October 30,1950 . This falcon is a rare winter visitor. Thomas McCamant (unpublished notes) stated that he saw one or two per year at various locations during $10 \mathrm{yr}$ of observations in Jackson County. Gabrielson and Jewett (1940) mention that there have been sight records in the county and consider the species to be a rare straggler west of the Cascade Mountains.

Falco sparverius. Sparrow Hawk.

Specimens: $17.7 \mathrm{~km}$ SW Prospect, male, December 27, 1952 ; Medford, male, June 1, 1962. The Sparrow Hawk is a very common permanent resident throughout the lower elevations of the county in the Chaparral-Oak Community.

Dendragapus obscurus. Blue Grouse.

This species is a fairly common resident in the Cascade and Siskiyou mountains in the Mixed Conifer and True Fir forests.

Bonasa umbellus. Ruffed Grouse.

Specimens: $12.9 \mathrm{~km}$ SW Prospect, male, January 21, 1959; $14.5 \mathrm{~km}$ SW Prospect, female, May 12, 1959. The Ruffed Grouse is a fairly common permanent resident in the Mixed Conifer Forest in the mountains of Jackson County; it occurs at lower elevations (valley foothills) during winter.

Colinus virginianus. Bobwhite.

The only recent record is of a male in May 1957 at the Game Ponds. Gabrielson (1931) reported a lone male observed near Brownsboro (about $12.9 \mathrm{~km}$ east of Fagle Point), August 23, 1923. This species was introduced many years ago (probably early 1900), but has been unsuccessful in this area (Gabrielson and Jewett, 1940).

Lophortyx californicus. California Quail.

Specimens: $6.4 \mathrm{~km} \mathrm{~N}$ Eagle Point, two males and one female, October 30, 1955; Ashland, male, May 9, 1971. This quail is a common to uncommon permanent resident in the Chaparral-Oak Community of the Lower Rogue River and Bear Creek valleys and foothills. The species breeds throughout its range. The latest nesting date is of a female hatching eight eggs on September 1, 1960, at Phoenix. 
Oreortyx pictus. Mountain Quail.

Specimen: Howard Prairie, female ?, fall 1960. The Mountain Quail probably occurs throughout the Mixed Conifer Forest of the county with the greatest number found at 610 to $1,372 \mathrm{~m}$. The species has been seen many times on the slopes of Baldy and near the summit of Roxy Ann Peak. Gabrielson and Jewett (1940) considered it to be fairly common in the foothills around the Lower Rogue River Valley and cite egg records from Brownsboro (about $12.9 \mathrm{~km}$ east of Eagle Point).

Phasianus colchicus. Ring-necked Pheasant.

Specimens: Several from Lower Rogue River Valley of both sexes and all months. Introduced. This pheasant is a common permanent resident throughout the Lower Rogue River and Bear Creek valleys up to about $610 \mathrm{~m}$. It is most often found in agricultural lands, particularly in fields but also in orchards.

Alectoris chukar. Chukar.

Introduced. About 2,000 were introduced by the Oregon State Game Commission to various areas of Jackson County after August 21, 1957. Releases were also made in March and September 1958 and July 1959. Fifty (each) were released at Pinehurst, White City, and Pilot Rock (on eastern Siskiyou Mountains) on July 20, 1962. Sight records of this species were periodically made shortly after the release periods but since the last release in 1962 none have been reported.

Perdix perdix. Gray Partridge.

Introduced. About 1,500 were introduced to the county by the Oregon State Game Commission after 1960. The birds were released in March and August of 1960, and in March 1961-62. Birds were periodically sighted shortly after the release periods, especially east of Ashland near Pompadour Bluffs. The latest record was made in 1964.

Grus canadensis. Sandhill Crane.

The Sandhill Crane is a fairly regular migrant. Earliest, April 5, Game Ponds; latest, October 4, Talent. 'Two cranes were seen during August 1963 at Howard Prairie Reservoir and one observed on November 10, 1963, at Hoover's Lakes. Migrants west of the Cascades have also been reported from such areas as Portland (Aud. Field Notes 1961:433), Corvallis (Aud. Field Notes 1965:506), Eugene (Gullion 1948, 1951), and Diamond Lake in Douglas County (Thatcher 1947). Gullion (1947) reports this species breeding in western Deschutes County and suggests that it breeds at lakes and reservoirs of the Cascade Mountains. 
Rallus limicola. Virginia Rail.

Specimen: Ashland, male, December 8, $1967 ; 8.1 \mathrm{~km}$ E Jacksonville, male, November 20, 1971. This rail is an uncommon resident in the Medford-Phoenix-White City area. The first recent record of the Virginia Rail was of an immature at Voorhies Crossing on July 23, 1961. This area was flooded by Bear Creek during the winter of 1962. The existing cattail marsh was heavily silted and willows took over the following spring. Since then most of the reports have been from the Game Ponds and a marsh just east of Medford where single nests were found in 1970 and 1971 . The Virginia Rail probably breeds sparingly in isolated marshes north and east of Medford.

Porzana carolina. Sora.

Specimen: Medford, male, April 28, 1972. The Sora is a rare permanent resident and possible breeder at the Game Ponds. The first Jackson County record of the Sora was of a bird killed striking a window in Medford on May 20, 1964. The late Walt Cavanough (personal communication) of the Oregon State Game Commission stated that he had seen Soras during several summers in the edges of the Game Ponds where cattails were abundant. There are also winter records from the Game Ponds, January 1, 1965, and February 18, 1965 ; it has been reported less frequently from scattered cattail marshes from Medford north to the Rogue River and east to near the base of Roxy Ann Peak.

Fulica americana. American Coot.

The coot is a common to very common migrant and winter resident; it is fairly common as a breeding species. The coot may be found on almost any body of water during migration and during the winter in the Lower Rogue River and Bear Creek valleys. The species breeds most commonly at the Game Ponds and at Hoover's Lakes.

Charadrius vociferus. Killdeer.

Specimen: $3.2 \mathrm{~km}$ S Medford, sex?, May 27, 1969. The Killdeer is a very common and widely distributed species throughout the county on residential lawns, fields, and stream and lake shores. It breeds throughout its range. Downy young have been observed as early as April 6.

Pluvialis squatarola. Black-bellied Plover.

This plover is very rare. One individual was observed on a lagoon on the Rogue River near Shady Cove by three observers on April 2, 1960. Gabrielson and Jewett (1940) consider this species an uncommon migrant and winter resident along the Oregon coast. Gullion (1951) considers the Black-bellied Plover to be a common fall migrant in the southern Willamette Valley, Oregon, reporting a record of 91 birds in mid-October. Marshall (1959) reports records for October 
and September, and one spring record on May 14, 1958, at Harney Lake (Harney County).

Capella gallinago. Common Snipe.

Specimens: Two, $12.9 \mathrm{~km}$ SW Prospect, sex ?, September 26, 1947, and male, December 6, 1948. This species is a fairly common summer resident and breeding species and an uncommon winter resident. The Common Snipe is found throughout the lower Jackson County, probably not above Prospect $(792 \mathrm{~m})$, and is usually reported on the Medford CBCs, averaging about nine birds per count.

Numenius americanus. Long-billed Curlew.

The Long-billed Curlew is very rare; one was recorded at Hoover's Lakes April 8, 1961. Gabrielson and Jewett (1940) consider this curlew to be casual west of the Cascades on the basis of specimens from Linn and Lincoln counties.

Actitis macularia. Spotted Sandpiper.

This sandpiper is a common to fairly common resident, found along almost any stream in Jackson County up to about $1,372 \mathrm{~m}$. The Spotted Sandpiper is an uncommon winter resident in the Lower Rogue River and Bear Creek valleys.

Tringa solitaria. Solitary Sandpiper.

This species is a rare visitor. One Solitary was sighted near Gold Ray Dam on September 11, 1966, and four were observed at Shady Cove on August 29, 1961 (Browning, 1966b). Gabrielson and Jewett (1940) consider it a straggler to western Oregon and cite a specimen taken at Portland on May 5, 1930. Evenden et al. (1950) consider this species a rare spring migrant in the Willamette Valley, and Gullion (1951) reports both spring and fall records.

Tringa melanoleucus. Greater Yellowlegs.

The Greater Yellowlegs is a fairly common migrant and rare winter visitor. Latest, 5 October, Phoenix. It has been reported once at Hyatt Reservoir and once at Howard Prairie Reservoir. Several sight records are from Hoover's Lakes. This species has been reported in winter only once, December 30, at Hoover's Lakes (Medford CBCs).

Tringa flavipes. Lesser Yellowlegs.

This species is an uncommon visitor that has occurred at Hoover's Lakes in April, July, and September and twice near Shady Cove in July. Earliest, April 15, Hoover's Lakes; latest, September, Hoover's Lakes.

Catoptrophorus semipalmatus. Willet.

Photograph: Hoover's Lakes, May 21, $1962(\mathrm{JH})$. The Willet is a rare spring visitor. Three Willets were seen at Hoover's Lakes on April 20, 1965, two on April 28, 1958, and one on May 21, 1962. One was reported near Shady Cove on April 10, 1962. 


\section{Calidris melanotos. Pectoral Sandpiper.}

Photograph: Hoover's Lakes, April 9, 1964 (JH). This sandpiper is known only from the photographic record (Browning 1966b). Gabrielson and Jewett (1940) list two fall records of the Pectoral Sandpiper from Multnomah and Lincoln counties and Gullion (1951) considers this species as a common (italics mine) fall migrant in the southern Willamette Valley.

Calidris bairdii. Baird's Sandpiper.

This peep sandpiper is a very rare visitor in spring, known only from two sight records: April 10, 1964, and May 5, 1965, at Hoover's Lakes. Both records were made by experienced observers, and during each observation Calidris mauri (Western Sandpiper) and C. minutilla (Least Sandpiper) were present for comparison. Gabrielson and Jewett (1940) cite several specimens from the coast taken during the fall and a flock seen (one specimen collected) in Wallowa County. Gullion (1951) considers Baird's Sandpiper to be a common fall migrant in the southern Willamette Valley.

Calidris minutilla. Least Sandpiper.

This small sandpiper is a fairly common spring migrant and less common fall migrant in the White City area. Earliest spring, February 27, Hoover's Lakes; latest spring, late May. Earliest fall, July 14, Howard Prairie Reservoir; latest fall, September 24, Phoenix. Six individuals were sighted on the Medford CBCs at Hoover's Lakes on December 30, 1960.

Calidris alpina. Dunlin.

The Dunlin is a fairly common spring migrant in the White City area. Earliest, April 8, Hoover's Lakes; latest, June 10, Hoover's Lakes. Six were recorded on a Medford CBC on December 28, 1962.

Calidris pusilla. Semipalmated Sandpiper.

This sandpiper is a very rare visitor. One bird identified as the Semipalmated Sandpiper was seen at Hoover's Lakes on April 14, 1964. There are no known specimens of this species in Oregon and it should remain on the Oregon hypothetical list (Gabrielson and Jewett 1940:604).

Calidris mauri. Western Sandpiper.

The Western Sandpiper is an uncommon spring and fall migrant in Bear Creek Valley and the White City area. Earliest spring, April 5, Game Ponds; latest spring, early May, Hoover's Lakes; earliest fall, July 13, Hoover's Lakes; latest fall, November 28, Phoenix.

Limnodromus spp. Dowitcher.

Both Limnodromus griseus and $L$. scolopaceus probably occur in Jackson County, but available records do not provide adequate evidence for species documentation. Dowitchers are fairly common 
migrants with records from Lower Bear Valley (Phoenix to Gold Ray Dam area) and the White City area. Earliest spring, March 31, Medford; latest spring, May 6, Medford. The only fall record is of four birds on July 14 at Howard Prairie Reservoir. One Dowitcher was seen on Bear Creek near Phoenix on January 2, 1959.

Recurvirostra americana. American Avocet.

The avocet is a very rare visitor reported three times at Hoover's Lakes: summer 1960, May 20, 1963, and September 18, 1964. Gabrielson and Jewett (1940) cite two specimens taken near Corvallis (Benton County) on July 29, 1900.

Himantopus mexicanus. Black-necked Stilt.

The Black-necked Stilt is a very rare visitor. The only record of this species is of one at Hoover's Lakes on April 25, 1960, observed by two experienced observers.

Phalaropus fulicarius. Red Phalarope.

The Red Phalarope is a rare visitor occurring south of Shady Cove on the Rogue River where a pair were observed on November 13, 1960 (Browning 1966a). Alderson (1961) reports several inland records from northwestern Oregon for November and October.

Steganopus tricolor. Wilson's Phalarope.

Photograph: Hoover's Lakes, May $1962(\mathrm{JH})$. This phalarope is an uncommon migrant that formerly bred at Hoover's Lakes until 1969. Earliest, April 20, Hoover's Lakes; latest, August 7, Hyatt Reservoir. Gabrielson and Jewett (1940) consider the Wilson's Phalarope to be a rare straggler west of the Cascades and give April 21 (Malheur County) for their earliest date and September 22 (Harney County) for their latest date. These authors do not consider this species to breed west of the Cascades.

Lobipes lobatus. Northern Phalarope.

Photographs: Ashland May 21, 1965 (JH); Hoover's Lakes, June $1965(\mathrm{JH})$; Sam's Valley, August 24, 1963 (D'T). This phalarope is a rare migrant and has been seen at most bodies of water of the Chaparral-Oak Community. Gabrielson (1931) collected a specimen of Northern Phalarope from a flock of three at Savage Rapids (on the Rogue River, Josephine County) on May 17, 1922. The species is considered a very common migrant in the Willamette Valley (Gullion 1951).

Larus occidentalis. Western Gull.

Six Western Gulls were at the Game Ponds on May 30, 1961. Gabrielson and Jewett (1940) list inland records for Portland, The Dalles, and Corvallis of birds observed during winter. 


\section{Larus californicus. California Gull.}

Specimen: $12.9 \mathrm{~km}$ N Medford, female, August 6, 1958. Photograph: Hoover's Lakes, first year immature, March 27, $1962(\mathrm{JH})$. These are the only county records of this species that breeds to the east in Klamath County.

Larus delauarensis. Ring-billed Gull.

Specimen: Medford, sex ?, September 21, 1965. This gull is a regular uncommon spring visitor and irregular rare winter visitor in the Lower Rogue River and Bear Creek valleys. Earliest, February 24, Emigrant Reservoir; latest, May 17, Hoover's Lakes. 'The Ring-bill has been recorded twice on Medford CBCs, one on December 28, 1953, and two on December 30, 1965.

Larus pipixcan. Franklin's Gull.

The Franklin's Gull is a very rare visitor. An immature was sighted repeatedly by several observers north of Medford from April 25 to July 28, 1961, at both Hoover's Lakes and the Game Ponds (Browning 1966b). Jewett (1949) reported the Franklin's Gull breeding at Malheur National Wildlife Refuge in Harney County.

Larus philadelphia. Bonaparte's Gull.

Photograph: Hoover's Lakes, breeding plumage, May 20, 1962 (JH). The Bonaparte's Gull is an irregular and uncommon spring and fall migrant likely to occur in the Lower Rogue River and Bear Creek valleys in May and November. It is most frequently reported from the White City area.

Sterna forsteri. Forster's Tern.

The Forster's Tern is a very rare spring migrant; only two records exist during recent years at Hoover's Lakes and at the Game Ponds on May 30, 1960, and ? May 1961, respectively.

Hydroprogne caspia. Caspian Tern.

This large tern is a rure irregular fall visitor. 'The species was first reported in Jackson County at Fish Lake where two adults were seen on July 19, 1961 (Aud. Field Notes 1961:488). Three others were observed at Emigrant Reservoir in fall 1969 and 1970, and one at Agate Reservoir in fall 1970.

Chlidonias niger. Black Tern.

This dark tern is an uncommon spring and summer visitor on ponds in the White City area. Earliest, mid-May. This species formerly bred at Hoover's Lakes and the Game Ponds.

Synthliboramphus antiquum. Ancient Murrelet.

Specimen: Medford, male, winter plumage, March 3, 1966. Accidental. The Ancient Murrelet is known only from the above record (Browning 1972). Jewett (1951) cites a specimen of the species taken at Bend (Deschutes County) on November 18, 1950. 
Columba fasciata. Band-tailed Pigeon.

Specimens: Two females, $12.9 \mathrm{~km} \mathrm{SW}$ Prospect, September 15, 1948. The Band-tailed Pigeon is a fairly common migrant in the Mixed Conifer Forest area. The species probably breeds in the county. Bandtailed Pigeons have been reported twice in winter.

Zenaida macroura. Mourning Dove.

Specimens: $12.9 \mathrm{~km} \mathrm{SW}$ Prospect, sex ?, September 11, 1959; Medford, male, June 14, 1970. The Mourning Dove is an abundant permanent resident and breeding species throughout Jackson County in the Chaparral-Oak Community.

Tyto alba. Barn Owl.

Specimens: Several from various localities and dates. The Barn Owl is an uncommon permanent resident. The species has been reported only from the Rogue River Valley below Prospect and from Bear Creek Valley, although it probably occurs and breeds elsewhere in the county.

Otus asio. Screech Owl.

Specimens: $17.7 \mathrm{~km}$ NW Prospect, male, May 10, 1959; $12.9 \mathrm{~km}$ SW Prospect, female, January 17,1952 . This owl is a fairly common permanent resident in the Chaparral-Oak Community and Mixed Conifer Forest, but more common in the former in the valley foothills. Gabrielson and Jewett (1940) list a Screech Owl taken at Eagle Point on March 21, 1925.

Bubo virginianus. Great Horned Owl.

Specimen: $12.9 \mathrm{~km}$ SW Prospect, male, May 3, 1935. This large owl is a common permanent resident occurring throughout most of Jackson County, especially in the margins of the Chaparral-Oak Community and Mixed Conifer Forest.

Glaucidium gnoma. Pygmy Owl.

Specimens: Three, $12.9 \mathrm{~km}$ SW Prospect, female, November 11, 1959 ; male, November 14, 1951 ; male, December 7, 1947. This small owl is an uncommon permanent resident in the Mixed Conifer Forest and Chaparral-Oak Community. The Pygmy Owl has been seen in various localities in the Lower Rogue River and Bear Creek valleys as well as on Roxy Ani Peak, and at Oregon Switzerland, Gardner Reservoir, Prospect, and Shady Cove.

Speotyto cunicularia. Burrowing Owl.

Photographs: Several, different months, E Medford (D'T) ; Hoover's Lakes, May 11, 1963 (JH); White City, January 12, 1963 (JH). The Burrowing Owl formerly bred throughout the county in openings of the Chaparral-Oak Community in the Lower Rogue River Vulley. The species was a common breeding species in the Medford-White City area during the 1920's and 1930's (Carl Richardson, personal 
communication). Presently, this owl is considered a rare visitor in the White City-Agate Reservoir area.

Strix nebulosa. Great Gray Owl.

This large owl is uncommon in Jackson County. Jewett (in Gabrielson, 1931) saw a 7-yr-old specimen in a Medford store on December 14, 1918, and was told by a taxidermist that he had mounted three Great Gray Owls from near Prospect in the winter of 1917. Stevenson and Fitch (1933) saw one $11.3 \mathrm{~km}$ east of Ashland on December 16, 1932, and one south of Medford during the last week of December 1929. One Great Gray Owl was seen near the town of Rogue River on Foots Creek on January 26, 1959 (Alderson 1960). This species is a fairly common breeding bird at Fort Klamath (Klamath County).

Asio otus. Long-eared Owl.

The Long-eared Owl is a very rare winter visitor known only from a single sight record in castern Medford on December 29, 1964, during an unusual cold period and heavy snow. Gabrielson and Jewett (1940) report this owl as wintering sparingly in western Oregon.

Asio flammeus. Short-eared Owl.

The Short-eared Owl is an uncommon winter visitor in the MedfordWhite City area, most often observed at Hoover's Lakes. The largest concentration of this species was nine at Hoover's Lakes on January 2, 1965 (Aud. Field Notes 1965:411). Gabrielson (1931) cites one Shorteared Owl seen by Jewett "near Medford," Decembcr 19, 1918.

Aegolius acadicus. Saw-whet Owl.

Specimen: Prospect, male, January 24, 1951. This owl is an uncommon permanent resident that probably occurs wherever there is conifer forest. Specimens are cited from Jackson County by Gabrielson and Jewett (1940).

Phalaenoptilus nuttallii. Poor-will.

Specimen: Prospect, female, August 5, 1960. The Poor-will is an uncommon summer resident in the Chaparral-Oak Community, especially at Roxy Ann Peak. Adults were reported feeding young on Roxy Ann (at $762 \mathrm{~m}$ ) on July 20, 1971. The species is occasionally observed north of Medford and White City. Gabrielson and Jewett (1940) took a specimen on June 21, 1929, at Brownsboro (about 12.9 km E Eagle Point) and consider this species a regular summer resident in the eastern part of Jackson County and "probably other parts of the Rogue River Valley."

Chordeiles minor. Common Nighthawk.

Specimen: $12.9 \mathrm{~km} \mathrm{SW}$ Prospect, male, August 15, 1952. This common summer resident probably breeds throughout the ChaparralOak Community. Earliest, May 23, White City; latest, September 10, 1960 . 
Chaetura vauxi. Vaux's Swift.

The Vaux's Swift is a common summer resident in Mixed Conifer and True Fir forests. Migrant swifts occur in the Chaparral-Oak Community. Earliest, April 30, Medford; latest, September.

Archilochus alexandri. Black-chinned Hummingbird.

This hummingbird is an uncommon regular summer visitor, reported only from near Shady Cove since 1968. Earliest, March 26; latest August 15. Several pairs of Black-chinned Hummingbirds were reported in June 1970 and a young male was sighted July 25, 1970 (Aud. Field Notes 1970:710). Gabrielson and Jewett (1940) list three specimens taken in Oregon during June (1915, 1919, and 1925).

Calypte anna. Anna's Hummingbird.

Specimen: Central Point, sex ?, March 19, 1972. The Anna's Hummingbird is an irregular and rare winter visitor and a regular uncommon summer visitor in the Lower Rogue River and Bear Creek valleys. A male at Ashland on December 21, 1958 (Aud. Field Notes 1960:335) was the first Jackson County record. This species has been observed at the Star Ranger Station on the Applegate River in Mixed Conifer Forest during the spring and summer. The latest summer record is July 7, near Shady Cove in Chaparral-Oak. A male was collected at Brookings (Curry County) on March 21, 1966 (Browning and English 1967a). Zimmerman (1973) reviews recent distributional records of the species.

Selasphorus platycercus. Broad-tailed Hummingbird.

This hummingbird is a rare summer visitor reported only at a bird feeder near Shady Cove. Both males and females have been observed since 1968 during May and a young bird was reported on July 25, 1970. Although female Rufous, Allen's, and Calliope hummingbirds were present for comparison, I feel that the records of females and young are questionable. No recent records of the Broadtailed Hummingbird exist elsewhere in Oregon. Gabrielson and Jewett (1940) consider it to be a rare summer visitor to extreme eastern Oregon.

Selasphorus rufus. Rufous Hummingbird.

Specimen: Medford, sex ?, April 19, 1965. This species is a common summer resident, breeding throughout most of the county. Earliest, February 23, Gold Ray Dam; latest, October 25, Medford. Most individuals leave by the end of September.

Selasphorus sasin. Allen's Hummingbird.

A rare irregular summer visitor, Allen's Hummingbirds have been observed at Medford in April, at Shady Cove in May and July, at Talent in June, and at Phoenix in July and August. Earliest, April 1; latest, August 12. One was seen north of Brookings on April 12, 1969 
(Aud. Field Notes 1969:617) and one was observed at Crater Lake National Park (Klamath County) on July 6, 1964 (Browning 1966a).

Stellula calliope. Calliope Hummingbird.

Specimen: Ashland, sex ?, May 12, 1965. This small hummingbird is a common to fairly common valley migrant, and a fairly common breeding bird in the Cascade and Siskiyou mountains. Earliest, April 30, Ashland; latest, late September, Jackson County.

Megaceryle alcyon. Belted Kingfisher.

Specimens: Two males, $12.9 \mathrm{~km} \mathrm{SW}$ Prospect, March 28, 1961, and December 16, 1959. The Belted Kingfisher is a fairly common permanent resident in the Chaparral-Oak Community and higher elevations along the major tributaries of the Rogue River.

Colaptes auratus (auratus group) Common Flicker.

This group includes birds with yellow wing shafts. Specimen: $4.8 \mathrm{~km}$ SE Ashland, female, December 23, 1967. Birds of the auratus group are very rare; only one sight record, $3.2 \mathrm{~km}$ north of Talent during February 1962 (Browning 1966a), in addition to the specimen cited. Giles (1958) observed one on May 1, 1957, at Lower Klamath National Wildlife Refuge, Siskiyou County, California. Identifiable remains of a yellow-shafted bird were found on March 22, 1966, near Brookings, Curry County (Browning and English 1967b).

Colaptes auratus (cafer group) Common Flicker.

This group includes birds with red wing shafts. Specimens: Two females, $12.9 \mathrm{~km}$ SW Prospect, January 29, 1947, and April 8, 1946; $9.7 \mathrm{~km} \mathrm{~N}$ Prospect, male, April 18, 1935. Birds of the cafer group are common permanent residents throughout the county below the coniferous forests and may also be found at higher elevations during summer months where deciduous growth occurs.

Hybrids between the cafer and auratus groups have occurred rarely in Jackson County. Specimen: $9.7 \mathrm{~km} \mathrm{~N}$ Prospect, male, April 18, 1935. Photograph: Talent, November 6, 1961 (D'T). Browning (1966a) reports records from Talent on November 6, 1961, from Medford on February 1, 1964, and two records at Phoenix on December 14 to 22, 1964, and October 11, 1965.

Dryocopus pileatus. Pileated Woodpecker.

Specimens: Two, $12.9 \mathrm{~km}$ SW Prospect, female, February 21, 1946; male, January 17, 1946. This large woodpecker is an uncommon permanent resident in the Mixed Conifer Forest and is rare at lower elevations.

Melanerpes formicivorus. Acorn Woodpecker.

Specimens: Male and female, $17.7 \mathrm{~km}$ SW Prospect, April 20, 1949; NW Medford, female, May 9, 1971; $8.0 \mathrm{~km}$ W Butte Falls, male, May 14, 1971. The Acorn Woodpecker is a fairly common 
permanent resident in the Chaparral-Oak Community, especially the Lower Rogue River and Bear Creek valleys.

Asyndesmus lewis. Lewis' Woodpecker.

Specimens: Eight specimens from areas southwest of Prospect, collected during September of different years; $20.9 \mathrm{~km} \mathrm{~N}$ Medford, male, May 5, 1961. The Lewis' Woodpecker is a fairly common summer resident of the Chaparral-Oak Community and lower elevations of the Mixed Conifer Forest. The species is a common winter resident, the numbers varying from year to year during this season. It has been recorded on 10 of 13 Medford CBCs averaging 27 individuals per count; 145 were recorded on the December 30,1965 , count.

Sphyrapicus varius. Yellow-bellied Sapsucker.

Specimens: Eight specimens from $12.9 \mathrm{~km}$ SW Prospect, taken in various months and years. This sapsucker is a fairly common permanent resident throughout Jackson County.

Sphyrapicus thyroideus. Williamson's Sapsucker.

Rare. This sapsucker is known in Jackson County from two sight records and a specimen cited by Gabrielson and Jewett (1940) taken in the Siskiyou Mountains south of Ashland. An individual was observed near Howard Prairie Reservoir on September 8, 1958, and one was seen in the Siskiyou Mountains near the town of Siskiyou on May 30, 1960. Gabrielson and Jewett (1940) consider this species to be a summer resident of the summit and eastern slope of the Cascade Mountains. It may breed in the pine forests of the Cascade and Siskiyou mountains.

Dendrocopos villosus. Hairy Woodpecker.

Specimens: Seven specimens from the Prospect area from different months and years. The Hairy Woodpecker is an uncommon to fairly common permanent resident throughout most of the county. Gabrielson and Jewett (1940) give summer records from Butte Falls, Rustler Peak (1,892 km), Brownsboro, Four-mile Lake (Klamath County), and the Rogue River.

Dendrocopos pubescens. Downy Woodpecker.

Specimens: Eagle Point, male, February 10, 1926; $12.9 \mathrm{~km} \mathrm{SW}$ Prospect, male, December 16,1932. This small woodpecker is a fairly common permanent resident of the Rogue River and Bear Creek valleys and foothill stream valleys. Gabrielson and Jewett (1940) list a specimen taken at Medford May 21, 1919.

Dendrocopos nuttallii. Nuttall's Woodpecker.

This woodpecker is known to Jackson County only by the collection of a male and female in the vicinity of Ashland on February 3, and February 4, 1881 (Short 1965). Gabrielson and Jewett (1940) cite a specimen taken in the Umpqua Valley in August 1855, and these 
authors suggest that it is possible that this species may occur in southern Oregon near the California-Oregon State line. The A.O.U. Check-list (1957:328) gives southern Humboldt County, California, as the species' northern limit.

Dendrocopos albolarvatus. White-headed Woodpecker.

The White-headed Woodpecker is a rare permanent resident. There are two summer records in Jackson County: One was seen in Mixed Conifer Forest between Fish Lake and Willow Creek Reservoir on July 19, 1961, and one was observed chasing a Yellow-bellied Sapsucker in a ponderosa pine forest near Jenny Creek (extreme southeastern part of the county) on June 16, 1967. Stevenson and Fitch (1933) saw a male on December 16, 1932, in yellow pine at Lake of the Woods in the Cascade Mountains. Gabrielson and Jewett (1940) reported this species in mixed yellow pine and oak in northern Jackson County in the vicinity of Crater Lake National Park (probably north of Union Creek), the Siskiyou Mountains, and Rustler Peak (Cascade Mountains). Farner (1952) considers this woodpecker to be a rare summer resident in Crater National Park.

Picoides arcticus. Black-backed Three-toed Woodpecker.

Specimen: $16.1 \mathrm{~km} \mathrm{E}$ and $4.8 \mathrm{~km} \mathrm{~N}$ Ashland, male, May 1, 1960. The only recent records of this rare species are from Gardner Reservoir and near Wagner Butte $(1,829 \mathrm{~m})$ where one individual was seen on June 11, 1956, and March 15, 1961, respectively. Gabrielson and Jewett (1940) list the summit and western slope of the Cascades, and the Siskiyou Mountains in Jackson County as part of this woodpecker's permanent range.

Picoides tridactylus. Northern Three-toed Woodpecker.

The Northern Three-toed Woodpecker is rare and is known from two sight records. One was observed near Mount Ashland on May 18, 1962 , and one on the northern slope of Roxy Ann Peak on December 28, 1962. Gabrielson and Jewett (1940) list the Canadian Life Zone (=True Fir Forest?) of the Siskiyou Mountains for this species' range and consider it a permanent resident.

Tyrannus tyrannus. Eastern Kingbird.

This species is an occasional rare summer resident in the Hoover's Lakes area. Two Eastern Kingbirds were seen there on June 25, 1959, one on June 6, 1960, one May 27, 1961, and one May 30, 1962. A pair was reported near Ashland during June 1964. Gabrielson and Jewett (1940) consider this kingbird to be a common summer resident east of the Cascades.

Tyrannus verticalis. Western Kingbird.

Specimen: $19.3 \mathrm{~km} \mathrm{~N}$ Medford, male, May 5, 1961. The Western Kingbird is a common summer resident and breeding species in the 
Chaparral-Oak Community. Earliest, April 17, Phoenix; latest, about late August. An extremely late bird was seen on November 14 at Talent.

Myiarchus cinearascens. Ash-throated Flycatcher.

Specimen: $12.9 \mathrm{~km}$ SW Prospect, sex ?, June 18, 1960. This flycatcher is a common summer resident occurring along valley streams and foothills up to about $762 \mathrm{~m}$. Earliest, May 4, Little Butte Creek (near Eagle Point); latest, mid-September, Medford.

Sayornis nigricans. Black Phoebe.

Photographs: Applegate River near Ruch, June 19, 1963 (DT); same location, July $1963(\mathrm{JH})$. This phoebe is a rare regular summer resident. A pair of Black Phoebes was discovered nesting under a bridge near the Applegate River not far from Ruch in 1953, and a pair has been observed nesting there annually to this date. Richardson and Sturges (1964) discuss records from Medford, Ashland, and Grants Pass (Josephine County). Evenden et al. (1947) report a sight record of one from Linn County on May 24, 1936, and Jewett (1942) reports the only Oregon specimen, which was collected at Mercer (Lane County) June 1, 1936. Earlier records are discussed by Gabrielson and Jewett $(1940: 605)$, who placed the Black Phoebe on the Oregon hypothetical list. The earliest normal date for Jackson County is February 14; latest, September 4, both on the Applegate River near Ruch. Single nonbreeding birds have been observed at Ashland on March 26, 1962, at Trail during most of October 1964, and near Talent in March and May 1971. One was observed near Gold Ray Dam on Bear Creek on January 2 and 3, 1971.

Sayornis saya. Say's Phoebe.

Specimen: $12.9 \mathrm{~km}$ SW Prospect, female, March 7, 1947. The Say's Phoebe is a winter visitor and spring migrant in the Chaparral-Oak Community that arrives in late November and leaves in late March. It is reported infrequently on Medford CBCs in numbers up to three on any one count.

Empidonax flycatchers.

I have combined the available data of this genus because of the difficulty of accurately identifying these flycatchers. According to sight records five species of this genus have occurred in Jackson County in recent years, most of them regularly. The species reported are: Empidonax traillii (Willow Flycatcher), E. hammondii (Hammond's), E. oberholseri (Dusky), E. wrightii (Gray), and E. difficilis (Western). Earliest date for any Empidonax, April 27, Medford; latest, September 23, Medford. Until an adequate series of specimens are collected, the status of the species in Jackson County can be only stated in general terms. 
Contopus sordidulus. Western Wood Pewee.

Specimens: Four, Prospect area, May and June. The Western Wood Pewee is a common summer resident throughout most of the County from late April to early September.

Nuttallornis borealis. Olive-sided Flycatcher.

Specimens: $12.9 \mathrm{~km} \mathrm{SW}$ Prospect, male and female, May 29, 1947, and May 20, 1944, respectively. The Olive-sided Flycatcher is a fairly common to common summer resident in the True Fir Forest, and an uncommon migrant in the Rogue River and Bear Creek valleys. Earliest, April 30; latest, mid-September.

Eremophila alpestris. Horned Lark.

The Horned Lark is a fairly common permanent resident in the White City area. The rocky grassland that Gabrielson and Jewett (1940) described as habitat for this species east of Medford probably includes the area north of Medford to White City and east towards Gardner Reservoir.

Tachycineta thalassina. Violet-green Swallow.

Specimens: $12.9 \mathrm{~km}$ SW Prospect, female, July 18, 1952; N White City, male, February 27, 1971. This swallow is a very common migrant and summer resident. The species has been reported breeding at Payne Cliffs near Tombstone, both Table Rocks, and Pompadour Bluffs. Earliest, February 11, Game Ponds; latest, October 7, Medford.

Iridoprocne bicolor. Tree Swallow.

The Tree Swallow is a very common migrant and summer resident, breeding throughout most of the county. Earliest, February 7, Game Ponds; latest, October 4, Medford. Spring migrants often use Bear Creek as a flyway, and as many as several thousand may be seen daily in early April. Gabrielson and Jewett (1940) report that there was a colony utilizing dead trees drowned by the newly formed Fish Lake. The dead snags have subsequently been removed from reservoirs (see Purple Martin account).

Riparia riparia. Bank Swallow.

The Bank Swallow is an uncommon summer resident reported as a migrant from Medford, Phoenix, Ashland, Prospect, and Trail. A breeding colony of six individuals was discovered at McCloud on the Rogue River throughout the spring of 1963. To my knowledge there is only one published record of this species breeding in Oregon west of the Cascades (Gabrielson and Jewett 1940).

Stelgidopteryx ruficollis. Rough-winged Swallow.

Specimen: $12.9 \mathrm{~km}$ SW Prospect, female, May 19, 1947. The Rough-winged Swallow is an uncommon summer resident and migrant. It is slightly more abundant and more widely distributed than the Bank. Swallow. This swallow breeds along streams below 
$610 \mathrm{~m}$ where soft sandy stream banks are to be found. Earliest arrival February 24, Phoenix; latest departure, September 28, Medford.

Hirundo rustica. Barn Swallow.

This fork-tailed species is a fairly common migrant and summer resident in the Chaparral-Oak Community and Mixed Forest below 914 m. Earliest, April 6, Medford; latest, October 10, Medford. During the breeding season single pairs may be found nesting under almost every one of the many irrigation bridges scattered throughout the lower elevations of Jackson County.

Petrochelidon pyrrhonota. Cliff Swallow.

Specimens: $12.9 \mathrm{~km}$ SW Prospect, two females, May 5 and 19, 1947. This species is a common migrant and summer resident. Earliest, March 23, Game Ponds; latest, mid-September. The Cliff Swallow breeds on cliff faces and barns, probably throughout the ChaparralOak Community and Mixed Conifer Forest below about $914 \mathrm{~m}$.

Progne subis. Purple Martin.

This species is an uncommon summer resident that formerly nested in dead snags on the shore of Hyatt Reservoir until the snags were removed about 1960 . The Purple Martin is occasionally observed during summer at Howard Prairie Reservoir where it is thought to breed. Migrants are occasionally observed at lower elevations. Earliest, April 25, Shady Cove; latest, probably September.

Perisoreus canadensis. Gray Jay.

The Gray Jay is an uncommon permanent resident in the Mixed Conifer and True Fir forests of the Cascade and Siskiyou mountains. The only known breeding record of the Gray Jay in Jackson County is from Fish Lake where an adult was observed feeding fledged young in August 1967. It occurs at lower elevations during winter.

Cyanocitta stelleri. Steller's Jay.

Specimens: Six, $12.9 \mathrm{~km}$ SW Prospect, both sexes, January, February, May, October, and December. This jay is a fairly common permanent resident throughout Mixed Conifer Forest and low elevations in True Fir Forest. The Steller's Jay has been found breeding as low as $594 \mathrm{~m}$ at Ashland. This species is an uncommon winter resident in the Lower Rogue River and Bear Creek valleys.

Aphelocoma coerulescens. Scrub Jay.

Specimens: Ashland, male and female, November 1, 1964. The Scrub Jay is a common permanent resident in the Chaparral-Oak Community and Mixed Conifer Forest below $914 \mathrm{~m}$. It breeds throughout its range.

Pica pica. Black-billed Magpie.

Photograph: Ashland, one bird, May 30, 1963 (DT). An irregular visitor, small numbers of the Black-billed Magpie occur near 
Pompadour Bluffs in summer. Six were at Ashland on November 20, 1960, and two were reported on a Medford CBC (Aud. Field Notes $1962: 276$ ) on December 28, 1961. The species is also occasionally seen on the west slope of Baldy during the summer. It possibly breeds in the extreme southeastern part of the county.

Corvus corax. Common Raven.

Specimen: $12.9 \mathrm{~km}$ SW Prospect, sex?, November 16, 1955. The Common Raven is an uncommon permanent resident in the Mixed Conifer Forest. Ravens have been seen at Union Creek, Butte Falls (on Big Butte Creek, $773 \mathrm{~m}$ ), and at Howard Prairie and Willow Creek reservoirs.

Corvus brachyrhynchos. Common Crow.

Specimen: $12.9 \mathrm{~km}$ SW Prospect, male, April 1, 1954. The Common crow is an uncommon permanent resident throughout Jackson County, except in coniferous forests where it is rare. Crows are most commonly observed in the foothills of the Lower Rogue River and Bear Creek valleys and foothills east of Ashland.

Nucifraga columbiana. Clark's Nutcracker.

Specimens: $19.3 \mathrm{~km}$ NE Trail, male, date?; Mount Ashland, male, July 2, 1962. The species is an uncommon permanent resident in the Cascade and Siskiyou mountains. Browning (1966a) discusses summer records from the Siskiyou Mountains near Mount Ashland, including a sight record of at pair with one fledgling seen on July 25, 1965 , at about $2,134 \mathrm{~m}$. All reports of this species are from areas above $1,829 \mathrm{~m}$.

Parus atricapillus. Black-capped Chickadee.

Specimen: $3.2 \mathrm{~km}$ S Medford, male, May 24, 1969. This chickadee is a common permanent resident that is most often found in the Lower Rogue River and Bear Creek valleys.

Parus gambeli. Mountain Chickadee.

Specimen: $4.8 \mathrm{~km}$ SW Ashland, male, November 23, 1969. The Mountain Chickadee is a permanent resident in the county. It breeds in Mixed Conifer and True Fir forests above about $1,067 \mathrm{~m}$. The species winters sparingly in the Rogue River and Bear Creek foothills.

Parus rufescens. Chestnut-backed Chickadee.

Specimens: Four from near Prospect, both sexes, two taken in March, one in February, and one in November. This chickadee is an uncommon permanent resident in the True Fir Forest and to about 1,067 $\mathrm{m}$ in the Mixed Conifer Forest. The Chestnut-backed Chickadee winters sparingly in the Lower Rogue River and Bear Creek valleys and foothills. 
Parus inornatus. Plain Titmouse.

Specimen: $13.7 \mathrm{~km}$ SW Prospect, female, January 10, 1959. The Plain Titmouse is a common permanent resident in the ChaparralOak Community.

Psaltriparus minimus. Bushtit.

Specimens: $4.8 \mathrm{~km}$ NE Ashland near Emigrant Reservoir, male, May 30, 1970. The Bushtit is a very common resident in the Chaparral-Oak Community of the Lower Rogue River and Bear Creek valleys. The species remains in flocks during winter, dispersing into pairs by April.

Sitta carolinensis. White-breasted Nuthatch.

Specimens: $12.9 \mathrm{~km} \mathrm{SW}$ Prospect, sex ?, January 11, 1935; $17.7 \mathrm{~km}$ SW Prospect, sex ?, February 10, 1948; Ashland, female, January 8, 1968; S side Emigrant Reservoir, female, March 24, 1970. This nuthatch is a common to fairly common permanent resident that breeds throughout most of Jackson County below $1,219 \mathrm{~m}$ in oaks and Mixed Conifer Forest. It has been found nesting (eggs) as early as April 29, at Larson Creek.

Sitta canadensis. Red-breasted Nuthatch.

Specimens: Three from near Prospect, both sexes, March and December. The Red-breasted Nuthatch is an uncommon to fairly common permanent resident of the True Fir Forest and winters to the valley foothills.

Sitta pygmea. Pygmy Nuthatch.

This small nuthatch is a rare winter visitor known to have occurred twice in the Lower Bear Creek Valley. The first record of the Pygmy Nuthatch in Jackson County was of five reported on a Medford CBC on December 28, 1953 (Aud. Field Notes 1954:211): one was seen December 30, 1958, on a Medford CBC (Aud. Field Notes $1959: 243)$. Gabrielson and Jewett (1940) state they have commorly (italics mine) found this species in eastern Jackson County.

Certhia familiaris. Brown Creeper.

Specimens: $12.9 \mathrm{~km}$ SW Prospect, sex ?, November 28, 1951; Spring Creek (extreme SE Jackson County), male, June 13, 1967. The Brown Creeper is a fairly common breeding bird probably occurring throughout the conifer forests of the county, at least in the Cascade Mountains. This species winters throughout its breeding range and to the valley floor.

Chamaea fasciata. Wrentit.

The Wrentit is an uncommon permanent resident. Gabrielson (1931) reported several colonies of the Wrentit from the Rogue River Valley. Stevenson and Fitch (1933) reported a breeding colony of this species $11.3 \mathrm{~km}$ north of Medford. Presently, the Wrentit is 
known to breed in the foothills in Chaparral-Oak Community south of Ashland. Occasionally it is observed on Roxy Ann Peak and in the foothills west of Medford.

Cinclus mexicanus. Dipper.

Specimens: Prospect, female, March 10, 1935; $12.9 \mathrm{~km}$ SW Prospect, male, January 9,1935 . The Dipper is a fairly common resident frequenting mountain streams throughout most of the county except in the Chaparral-Oak Community of the Lower Rogue River and Bear Creek valleys.

Troglodytes aedon. House Wren.

Specimens: $12.9 \mathrm{~km}$ SW Prospect, male, April 30, 1947; $9.7 \mathrm{~km} \mathrm{SW}$ Prospect, male, April 26, 1944. The House Wren is a common summer resident. This wren breeds throughout the county, but more frequently it is found in the valley foothills and mountains in Mixed Conifer Forest. Earliest, April 26, near Prospect; probably leaves by late September or early October.

Troglodytes troglodytes. Winter Wren.

Specimens: Prospect, two males, September 15, 1934, and December 26, 1933. This small wren is a fairly common permanent resident in the True Fir Forest that may be found in the valley areas in winter where it of ten frequents riparian understory.

Thryomanes bewickii. Bewick's Wren.

The Bewick's Wren is a common permanent resident that is most often found in the Chaparral-Oak Community of Jackson County.

Telmatodytes palustris. Long-billed Marsh Wren.

Specimen: NE Medford, male, January 1971. Until recent years this marsh wren was considered a rare winter visitor. This wren has been considered common since the fall of 1963 and is regularly found in marsh habitat of the Lower Rogue River and Bear Creek valleys. It has been observed at the Game Ponds as late as June. Singing and territorial disputes at the latter location have been observed, although breeding has not been confirmed.

Catherpes mexicanus. Cañon Wren.

Specimen: Jenny Creek, extreme SE Jackson County, female, May 28, 1966. The Cañon Wren is an uncommon breeding bird in the county. All sight records of the species have been made in the eastern part of Jackson County. It has been observed on occasion at Fish Lake and once during August at Grizzly Creek (near Fish Lake). The female taken on May 28, 1966, was in breeding condition and was observed carrying food to a rimrock crack. Gabrielson and Jewett (1940) state that this wren crosses the Cascade Mountains to Jackson County and list a male taken at Ashland on February 21, 1924. 
Salpinctes obsoletus. Rock Wren.

Specimen: $1.6 \mathrm{~km}$ E Prospect, male, April 2, 1947. The Rock Wren is a fairly common summer resident and breeding bird at Pompadour Bluffs, both Table Rocks, and possibly elsewhere in similar habitat, although there are only two records of this species in other areas. One was observed at Ashland on February 10, 1964, and one at Emigrant Reservoir April 18, 1964.

Mimus polyglottos. Mockingbird.

Rare. Single individuals have been reported at Medford in 1958 and 1961-63 in March, April, November, and December, in 1970 in February through mid-March and May, at Phoenix in April 1963, and at Ashland in February 1965. Hyde (1940) reported one seen at Burns on May 25, 1940, and Sooter (1941) lists two from Malheur National Wildlife Refuge (Harney County) seen on July 25, and August 23, 1940. Fender (1951) and Walker (1955) report spring records from McMinnville and Nehalm Bay in western Oregon. Gabrielson and Jewett (1940) give the Steens Mountains (Harney County) as the known range in Oregon.

Toxostoma redivivum. California Thrasher.

Accidental. One stayed near a feeder $8.1 \mathrm{~km}$ west of Medford (Chaparral-Oak) from July 24 to October 20, 1967, and a bird was seen at the same feeder on February 4 to 25, 1968. The A.O.U. Checklist (1957) gives southern Humboldt, Trinity, and Shasta counties, California, as the northern limit of this species' range.

Toxostoma lecontei. Le Conte's Thrasher.

Accidental. One Le Conte's Thrasher was observed on the western slope of Pilot Rock (about $19.3 \mathrm{~km}$ southeast of Ashland) at $1,524 \mathrm{~m}$ in the Siskiyou Mountains on July 29, 1966, by three persons (Aud. Field Notes 1966:594). Central California is this species' northern range limit (A.Q.U. $1957: 428$ ).

Turdus migratorius. American Robin.

Specimens: Several from various localities and dates. The American Robin is a very common permanent resident throughout most of the county, increasing in numbers during the winter when roosts are formed. The largest roost reported contained about 30,000 birds near Gold Ray Dam during 1964-65. Robins breed throughout most of the county.

Ixoreus naevius. Varied Thrush.

Specimens: $12.9 \mathrm{~km}$ SW Prospect, two males December 1933, one male November $1934 ; 19.3 \mathrm{~km}$ NE Trail, sex ?, March 10, 1926. The Varied Thrush is a common to uncommon winter resident that possibly breeds in the Cascades. During winter this thrush frequents the valley in fluctuating numbers. 
Catharus guttatus. Hermit Thrush.

Specimens: Four specimens from Prospect, two in April, two in December; both sexes. The Hermit Thrush is a fairly common breeding bird and uncommon winter resident. The species breeds in the Mixed Conifer and True Fir forests. The lowest elevation for apparent breeding is indicated by a record of a singing male in Yank Gultch, southwest of Talent, at $732 \mathrm{~m}$, on June 26, 1960. It arrives $\mathrm{n}$ Jackson County in late April and normally departs in late September.

Catharus fuscescens. Veery.

The Veery is a rare migrant or visitor. The species was first reported in Jackson County in 1964 when one was observed near Shady Cove on May 24. One was seen at Talent on May 6, 1964, and one near Shady Cove May 28-29, 1965. Single birds were reported near Shady Cove in the summers of 1968,1969 , and 1970. There are several records from eastern Oregon (Gabrielson and Jewett, 1940).

Sialia mexicana. Western Bluebird.

Specimens: Four of both sexes near Prospect, February and March; Eagle Point, female, November 26, 1925; $19.3 \mathrm{~km}$ NE Trail, male, March 6, 1926. The Western Bluebird is a common to fairly common permanent resident. This bluebird frequents oak woodlands and some open conifer forests of the Chaparral-Oak Community and the Mixed Conifer Forest. It is most commonly observed in the foothills of the Lower Rogue River and Bear Creek valleys. Winter populations during 1962 were greatly reduced during a week of temperatures near $-17 \mathrm{C}$.

Sialia currucoides. Mountain Bluebird.

Photographs: White City, February $1962(\mathrm{JH})$; near Old Military Bridge, March 17, 1964 (DT). The Mountain Bluebird is an uncommon breeding bird in the True Fir Forest of the Cascade and Siskiyou mountains. The species is a rare irregular winter visitor to the Lower Rogue River and Bear Creek valleys.

Myadestes townsendi. Townsend's Solitaire.

Specimens: $12.9 \mathrm{~km}$ SW Prospect, female, April 3, 1947, male June 30, 1951. Gabrielson and Jewett (1940) report numerous records from the eastern part of the county in the valley foothills. Gabrielson collected an immature barely able to fly on the western base of Mount McLoughlin on July 27, 1926. Recent records of this thrush suggest that it breeds in the high Cascades and probably in the Siskiyou Mountains of the True Fir Forest. During fall and winter this species occasionally wanders to the foothills east of Bear Creek, and it has been reported at Ashland and at Hoover's Lakes in the spring. 
Polioptila caerulea. Blue-gray Gnatcatcher.

Photographs: Roxy Ann Peak, June 1963 (JH) ; June 6, 1963 (DT). This species has bred in Jackson County for a number of years. Breeding was confirmed by the location of a nest on Roxy Ann Peak during the spring of 1963 (Richardson and Sturges 1964). During that year the nesting pair was unsuccessful in raising young. Since then, the Blue-gray Gnatcatcher has been observed breeding on Roxy Ann Peak and near Ashland. Four pairs of gnatcatchers were observed on Roxy Ann Peak in 1970 and six pairs in 1971 with one nest found each year. Earliest, May 7, Gardner Reservoir; latest, June 27, Roxy Ann Peak. Undoubtedly the departure date for this species is much later than indicated from available observations.

Gabrielson and Jewett (1940) do not list the Blue-gray Gnatcatcher for Oregon. Pruitt (1950) reports two records from Lane County, six near Thurston on April 26, 1949, and one at Eugene on May 26 to June 2, 1949. The normal range of this species extends north to Trinity and Siskiyou counties, immediately to the south of Jackson County (A.O.U. $1957: 450$ ).

Regulus satrapa. Golden-crowned Kinglet.

Specimen: $19.3 \mathrm{~km}$ NE Trail, male, March 7, 1926. The Goldencrowned Kinglet is a common permanent resident throughout the True Fir Forest of the county. It is occasionally found in the Lower Rogue River and Bear Creek valleys during winter.

Regulus calendula. Ruby-crowned Kinglet.

Specimens: Four from near Prospect, both sexes, January and March. This kinglet is a common permanent resident throughout most of Jackson County. The species breeds in Mixed Conifer Forest and possibly True Fir Forest and winters in the low elevations of the former and the Chaparral-Oak Community.

Anthus spinoletta. Water Pipit.

Specimens: Four taken near Prospect, both sexes, three in March, one in October. The Water Pipit is a common to fairly common fall migrant and winter resident. Earliest, July 12, Phoenix; latest, April. In winter pipits are most often seen at Hoover's Lakes.

Bombycilla garrulus. Bohemian Waxwing.

Specimen: Near Ashland, female, May 13, 1969. This waxwing is a rare irregular winter visitor to Jackson County with sight records from Medford in December, January, and February.

Bombycilla cedrorum. Cedar Waxwing.

Specimens: Eight, $12.9 \mathrm{~km}$ SW Prospect, both sexes, January, June, and November. The Cedar Waxwing is a very common and fairly regular migrant and permanent resident in most of Jackson County. It is abundant in Bear Creek Valley during some springs. 
Phainopepla nitens. Phainopepla.

Accidental. This species has occurred once in Jackson County where a bird was observed at Barneburg Hill south of Medford on March 15, 1961 (Browning 1966b). Marshall (1959) collected one Phainopepla $16.1 \mathrm{~km}$ north of Frenchglen (Harney County) on May 17, 1957, apparently the first Oregon specimen.

Lanius excubitor. Northern Shrike.

Specimen: Central Point, female, January 18, 1970. The Northern Shrike is a fairly regular winter visitor in the Lower Rogue River and Bear Creek valleys and foothills. This shrike has been recorded on 4 of 13 Medford CBCs and the highest count was two individuals. The species arrives in September and departs in April.

Lanius ludovicianus. Loggerhead Shrike.

This shrike is an uncommon permanent resident of the Lower Rogue River and Bear Creek valleys; most often seen in winter. Jewett collected one at Medford on March 19, 1934 (Gabrielson and Jewett 1940). These authors consider the Loggerhead Shrike to be rare west of the Cascade Mountains.

Sturnus vulgaris. Starling.

Specimen: $12.9 \mathrm{~km}$ SW Prospect, female, December 26, 1958. The Startling was first observed in Jackson County on February 8, 1954. It now breeds throughout the county below $610 \mathrm{~m}$ and is considered a very common breeding species. In winter the population increases in number when this species is considered a common to abundant winter resident.

Vireo huttoni. Hutton's Vireo.

Specimen: $12.9 \mathrm{~km}$ SW Prospect, sex ?, December 1, 1948. The Hutton's Vireo is a rare to common permanent resident. Six eggs of this vireo and five eggs of Brown-headed Cowbird (Molothrus ater) were found in a nest near Medford on July 9, 1965. The nest and eggs are deposited at Southern Oregon College.

Vireo solitarius. Solitary Vireo.

Specimens: $12.9 \mathrm{~km}$ SW Prospect, male, May 19, 1944; $17.7 \mathrm{~km}$ SW Prospect, male, May 19, 1947. The Solitary Vireo is a common summer resident throughout most of the county in Mixed Conifer Forest along streams. Earliest, March 19, Medford; latest November 11, Phoenix.

Vireo olivaceus. Red-eyed Vireo.

This vireo is a rare and irregular migrant and summer visitor from May to September (Browning 1966a). Kridler (1965) has records for May, June, August, and September from southeastern Oregon near Burns (Harney County). The A.O.U. Check-list (1957) gives northern Oregon as the southern limit of this vireo's normal range. 
Vireo gilvus. Warbling Vireo.

Specimen: Ashland, male, May 18, 1955. The Warbling Vireo is a common summer resident in Mixed Conifer Forest throughout the county. Earliest, April 18, Ashland; latest September 19, Medford.

Mniotilta varia. Black and White Warbler.

This eastern warbler was observed at Talent on October 7, 1963. Kridler and Marshall (1962) took a female at Malheur National Wildlife Refuge (Harney County) on September 17, 1960, the first specimen for Oregon.

Vermivora peregrina. Tennessee Warbler.

Accidental. An immature Tennessee Warbler was observed feeding with a migrant flock of Orange-crowned (Vermivora celata) and Wilson's Warblers (Wilsonia pusilla), and Warbling Vireos (Vireo gilvus) near Shady Cove on September 11, 1969. This species was reported the same year from Terrace, western British Columbia on August 14 (Aud. Field Notes 1969:88). Littlefield and Anderson (1971) list 11 records of the Tennessee Warbler in Oregon; nine have been recorded at Malheur National Wildlife Refuge (Harney County), and one from the Wallowa Mountains (northeastern Oregon) in addition to the Jackson County record. Littlefield and Anderson (1971) regard the species as an occasional spring and fall migrant in southeastern Oregon. The Tennessee Warbler is listed as a rare straggler in eastern Washington (Larrison and Sonnenberg 1968) with no spring records. In California the species is considered a regular but rare fall migrant (Aud. Field Notes 1970:94; Am. Birds 1971: 104-105).

Vermivora celata. Orange-crowned Warbler.

Specimens: Four, $12.9 \mathrm{~km}$ SW Prospect, both sexes, April and May. The Orange-crowned Warbler is a regular and common summer resident and migrant and is a fairly regular winter resident in the Lower Rogue River and Bear Creek valleys. This warbler has been reported in the county in almost every month, but is most numerous between mid-April to late September when it may be found in the ChaparralOak Community. Jewett found it nesting at Goldhill on May 16, 1916 (Gabrielson and Jewett 1940).

Vermivora ruficapilla. Nashville Warbler.

Specimens: Four, SW Prospect, both sexes, April and May. The Nashville Warbler is a common summer resident in the Mixed Conifer Forest. Earliest, April 20, Ashland; latest, August 28, Phoenix.

Dendroica petechia. Yellow Warbler.

The Yellow Warbler is a common summer resident throughout most of Jackson County, especially wooded streams below $914 \mathrm{~m}$. Earliest, April 28, Pompadour Bluffs; latest, September 17, Medford. 
Dendroica coronata. Yellow-rumped Warbler.

The yellow-throated subspecies, auduboni, and the white-throated subspecies, coronata, are generally easy to distinguish in the field so they are treated sepurately here.

Dendroica coronata coronata. Fairly common migrant and uncommon winter resident. This subspecies is reported most often in the Lower Rogue River and Bear Creek valleys. Spring migration peaks from April 1 to 15 . One or two nominate coronata are recorded annually on the Medford CBCs.

Dendroica coronata auduboni. Specimens: Three, $12.9 \mathrm{~km}$ SW Prospect, male, April 10, 1946, female April 11, 1946, and male May 29, $1934 ; 4.8 \mathrm{~km} \mathrm{~N}$ Prospect, female, June 8, 1934. The yellow-throated subspecies is a fairly common permanent resident that breeds in the mountains in Mixed Conifer and True Fir forests and winters in the valley areas. During spring migration the number of birds increases between April 1 and 15 in the valley.

Dendroica nigrescens. Black-throated Gray Warbler.

Specimen: $3.2 \mathrm{~km} \mathrm{~S}$ Medford, male, May 24, 1969. This mountain warbler is an uncommon migrant and summer resident. During migration it may be found throughout the county. In summer it breeds in the Mixed Conifer Forest of the Cascades and probably the Siskiyou Mountains. Earliest, March 31; latest, October 7, Medford.

Dendroica townsendi. Townsend's Warbler.

Specimen: $12.9 \mathrm{~km}$ SW Prospect, male, July 23, 1949. The Townsend's Warbler is an uncommon migrant and winter visitor. There are only two summer records of this warbler in Jackson County, the specimen cited and a bird observed on Roxy Ann Peak on August 20, 1961. The latter was probably an early fall migrant. Earliest, April 30, Ashland; latest, October 11, Larson Creek. Wintering birds or winter visitors have occurred in the Medford area in November, December, and January.

Dendroica occidentalis. Hermit Warbler.

The Hermit Warbler is an uncommon migrant in the foothills and mountains that probably breeds in coniferous areas of the county. A pair nested at Ashland in 1962 at $610 \mathrm{~m}$, far below normal breeding al titudes. The species arrives in the county in late April and departs in late August.

Seiurus noveboracensis. Northern Waterthrush.

Accidental. There are two sight records of this warbler in Jackson County; one was near Shady Cove on May 30, 1964, and one at the same location on August 16, 1970. Gabrielson and Jewett (1940) cite the first specimen collected in Oregon, a bird at Beaver (Tillamook County) on August 26, 1931. Kridler (1965) collected a female 
Northern Waterthrush at Malheur National Wildlife Refuge (Harney County) on May 9, 1961, and another was seen there on December 21, 1963 (Aud. Field Notes 1964:376).

Oporornis tolmiei. MacGillivray's Warbler.

Specimens: Four, $12.9 \mathrm{~km}$ SW Prospect, both sexes, various dates in May; Ashland, male, May 4, 1969. The MacGillivray's Warbler is a fairly common summer resident throughout most of the county in brushy areas of the foothills and mountains below 1,219 m. Earliest, April 19, Medford; the species departs in early October.

Geothlypis trichas. Yellowthroat.

The Yellowthroat is an uncommon migrant and summer resident. It may be found in suitable habitat below $914 \mathrm{~m}$. Earliest, April 19, Medford; latest, October 1, Medford.

Icteria virens. Yellow-breasted Chat.

Specimens: $12.9 \mathrm{~km}$ SW Prospect, male, May 17, 1947, and sex ?, June 9, 1947. The chat is a common summer resident along streams in the Chaparral-Oak Community. Earliest, April 24, Phoenix; latest, September.

Wilsonia pusilla. Wilson's Warbler.

Specimens: $12.9 \mathrm{~km}$ SW Prospect, male, May 6, 1944; Ashland, male, 1971. This warbler is a common summer resident, breeding in.. Mixed Conifer Forest of the Cascade Mountains. Earliest, April 16, Medford; latest late September, Bear Creek Valley.

Setophaga ruticilla. American Redstart.

The American Redstart is a rare breeding species. A pair with four young was discovered in deciduous forest along the Rogue River near Shady Cove on July 2, 1970 (Bertrand et al. 1973). Kridler and Marshall (1962) report collecting a female at Malheur National Wildlife Refuge (Harney County) on September 8, 1960. There are two sight records at Medford; a male and female in May 1957, and a male in May 1962. Gabrielson and Jewett (1940) consider the redstart to be a casual migrant and possible summer resident of the Blue Mountain district of northeastern Oregon.

Passer domesticus. House Sparrow.

Specimens: 12.9 km SW Prospect, male, April 16, 1951; Ashland, female, February 5, 1961. This species is a common permanent resident throughout Jackson County near human dwellings.

Sturnella neglecta. Western Meadowlark.

Specimens: Agate Desert near White City, male, December 30, $1934 ; 12.9 \mathrm{~km}$ SW Prospect, April 15, 1949. The Western Meadowlark is a very common permanent resident throughout the ChaparralOak Community. A few birds occur in the open grasslands of the Mixed Conifer Forest below $762 \mathrm{~m}$. 
Xanthocephalus xanthocephalus. Yellow-headed Blackbird.

This blackbird is an uncommon summer resident and occasional winter visitor near White City. Two to five pairs of the species breed at the Game Ponds. It probably breeds at nearby Hoover's Lakes. Gabrielson and Jewett (1940) consider the species to be an irregular visitor west of the Cascades.

Agelaius phoeniceus. Red-winged Blackbird.

Specimens: Four, near Prospect, both sexes, March, April, May, and August. The Red-winged Blackbird is a very common permanent resident below $762 \mathrm{~m}$. The species breeds along the Lower Rogue River and Bear Creek and tributaries and marsh edges of ponds and valley reservoirs. It is an abundant winter resident in the valley floor.

Agelaius tricolor. Tricolored Blackbird.

Specimens: Six, $1.6 \mathrm{~km} \mathrm{NW}$ White City, three males and three females, June 2, 1960. The Tricolored Blackbird was formerly thought to be found in Oregon only in Klamath County (Gabrielson and Jewett 1940). In the summer of 1956 Richardson (1961) saw 15 to 20 in Medford and in May 1957 he saw several hundred $4.8 \mathrm{~km}$ east of Medford. Thomas McCamant discovered the species nesting east of Central Point on June 2, 1958 (Aud. Field Notes 1958:379). Richardson (1961) collected three nests with three eggs each, and also the three males and three females cited. The marsh at the White City collection locality was drained in 1961 , but a colony was located $1.6 \mathrm{~km}$ east of Eagle Point (Richardson and Sturges 1964). On the basis of these records and winter occurrences, the Tricolored Blackbird is now considered a very common local permanent resident in Jackson County.

Icterus cucullatus. Hooded Oriole.

Accidental. Two adult males with an immature or adult female were seen at Ashland on May 15, 1963, and a male and female were observed south of Ruch on October 1, 1964 (Browning 1966b). A female was reported at Malheur National Wildlife Refuge (Harney County) on May 29, 1964 (Aud. Field Notes 1964:475) and a male was observed at the south jetty of the Columbia River on April 26, 1969 (Aud. Field Notes $1969: 618$ ). The A.O.U. Check-list (1957) gives central California as the Hooded Oriole's northern range limit.

Icterus galbula. Northern Oriole.

Specimen: $12.9 \mathrm{~km}$ SW Prospect, sex ?, April 29, 1959; Roxy Ann Peak, male, May 10, 1970. The Northern Oriole is a common migrant and breeding species in the Chaparral-Oak Community. Earliest, March 22, Medford; latest, October 29, Medford. 
Euphagus cyanocephalus. Brewer's Blackbird.

Specimens: Two, $1.6 \mathrm{~km}$ E Prospect, female, April 12, 1947, and male, March 29, 1947; $9.7 \mathrm{~km}$ N Prospect, female, April 27, 1935; Ashland, two males, May 7 and 25, 1968. This blackbird is a very common permanent resident and breeding species in the ChaparralOak Community and Mixed Conifer Forest.

Molothrus ater. Brown-headed Cowbird.

Specimens: Four, $12.9 \mathrm{~km}$ SW Prospect, both sexes, in May, June, and July. The Brown-headed Cowbird is a fairly common summer resident and an uncommon winter resident in Jackson County. It occurs with mixed flocks of blackbird species in the valley during winter. In spring the cowbird population increases and the species disperse throughout most of the county, especially to the Mixed Conifer Forest. Gabrielson and Jewett (1940) consider the species a rare straggler to western Oregon on the basis of a specimen collected in Lane County in 1925 (Jewett 1930) and a specimen collected there in 1930. Thatcher (1953) collected an immature bird in Medford on July 11, 1950, and suggested that Jackson County offers a suitable breeding habitat for the Brown-headed Cowbird. Specimen evidence and observed territorial displays substantiate this species as a breeding bird in Jackson County.

Piranga ludoviciana. Western Tanager.

Specimens: Seven, $12.9 \mathrm{~km}$ SW Prospect, both sexes, in May, June, and September. The Western Tanager is a common migrant in the Lower Rogue River and Bear Creek valleys and common summer resident in Mixed Conifer and True Fir forests. Earliest, April 9, Jacksonville; latest September 19, Medford.

Pheucticus melanocephalus. Black-headed Grosbeak.

Specimens: Three, $12.9 \mathrm{~km}$ SW Prospect, both sexes, May and June. This species is a common summer resident in the Lower Rogue River and Bear Creek valleys; it arrives in early April and departs in late September. It is fairly common in Mixed Conifer Forest at least near Ashland and Jacksonville.

Passerina amoena. Lazuli Bunting.

Specimens: $3.2 \mathrm{~km} \mathrm{SW}$ Prospect, male, June 1, 1935; $12.9 \mathrm{~km} \mathrm{SW}$ Prospect, sex ?, June 11, 1946. The Lazuli Bunting is a fairly common summer resident in the Chaparral-Oak Community. Earliest, April 30, Larson Creek; latest, early September, Bear Creek Valley.

Hesperiphona vespertina. Evening Grosbeak.

Specimens: $12.9 \mathrm{~km}$ SW Prospect, male and female, February 1, 1949; Ashland, male, May 27, 1971. The Evening Grosbeak is a fairly common permanent resident occurring sporadically throughout most of Jackson County. The species frequents the Chaparral-Oak Com- 
munity in winter and spring and is occasionally seen in the Cascades in Mixed Conifer Forest during summer. There is one unconfirmed report of the Evening Grosbeak breeding in the Siskiyou Mountains and Gabrielson and Jewett (1940) report a single breeding record from the western base of Mount McLoughlin.

Carpodacus purpureus. Purple Finch.

Specimens: Ten, near Prospect, both sexes, January, April, May, and June; Ashland, male, February 9, 1924, female, February 27, 1966. The Purple Finch is a fairly common permanent resident in the Mixed Conifer and 'True Fir forests of the county. It visits low elevations during winter.

Carpodacus cassinii. Cassin's Finch.

Specimens: Prospect, one male, two females, November 4, 1935. This finch is a fairly common permanent resident that breeds in the True Fir Farest of Jackson County, especially in the Cascades. It visits low elevations during winter.

Carpodacus mexicanus. House Finch.

Specimen: $12.9 \mathrm{~km}$ SW Prospect, sex ?, June 9, 1947. The House Finch is a common permanent resident in the Chaparral-Oak Community, decreasing slightly in numbers during winter. It breeds primarily in residential locations.

Pinicola enucleator. Pine Grosbeak.

The Pine Grosbeak is an irregular and rare spring visitor. This species has occurred in Jackson County on three occasions: one each near Howard Prairie Reservoir on May 30, 1960, and on May 30, 1965, and one was reported east of Mount Ashland on June 30, 1961 (Browning 1966b). Gabrielson and Jewett (1940) consider the species to be an irregular winter visitor to eastern Oregon.

Leucosticte tephrocotis. Gray-crowned Rosy Finch.

This species possibly breeds on Mount McLoughlin. Vernon Bailey (in Gabrielson and Jewett 1940) saw a flock of 20 birds above timberline on Mount McLoughlin between August 23 and 30, 1916. There are no recent records from the county.

Spinus pinus. Pine Siskin.

Specimens: Two, $12.9 \mathrm{~km}$ SW Prospect, females, April 14, 1947, and May 1, 1946; Ashland, male and female, May 10, 1964. The Pine Siskin is a common permanent resident in the Mixed Conifer Forest. It occasionally winters in the Lower Rogue River and Bear Creek valleys and is common there during spring and fall.

Spinus tristis. American Goldfinch.

Specimens: Two, $12.9 \mathrm{~km}$ SW Prospect, male, April 21, 1959, female, May 1, 1947. This goldfinch is a common permanent resident in the 
Chaparral-Oak Community of the county. In winter it may be found with flocks of Lesser Goldfinches (Spinus psaltria).

Spinus psaltria. Lesser Goldfinch.

Specimen: $12.9 \mathrm{~km}$ SW Prospect, female, April 21, 1959. The Lesser Goldfinch is a permanent resident in the Chaparral-Oak Community of the Lower Rogue River and Bear Creek valleys. The species is slightly less common than the American Goldfinch (Spinus tristis). In winter it may be found with flocks of the latter species.

Spinus lawrencei. Lawrence's Goldfinch.

Photograph: Talent, fall 1962 (DT). This species is a very rare occasional visitor. One bird was captured in Medford on April 20, 1958, and then released and one was seen near Medford on June 7, 1967. The A.O.U. Check-list (1957) gives north-central California as the northern range limit of this species. Gabrielson and Jewett (1940) do not list the species for Oregon.

Loxia curvirostra. Red Crossbill.

Specimens: Two, $12.9 \mathrm{~km}$ SW Prospect, male and female, May 17, 1946. The Red Crossbill is an occasional winter and spring visitor. Sight records of the species have been made at Ruch, Trail, Medford, Gardner Reservoir, Oregon Switzerland, and Prospect. Thirty-nine individuals were recorded on a Medford CBC on December 27, 1956 (Aud. Field Notes $1957: 221$ ).

Chlorura chlorura. Green-tailed Towhee.

This towhee is a fairly common summer resident along the Cascade summit and east, and in the Siskiyou Mountains in Mixed Conifer Forest (Pinus ponderosa edge). Earliest, May 3, Larson Creek; latest, September 23, (Jackson County, in Gabrielson and Jewett 1940).

Pipilo erythrophthalmus. Rufous-sided Towhee.

Specimens: Three, $4.8 \mathrm{~km}$ SW Prospect, both sexes, January and November; 17.7 km SW Prospect, male, April 30, 1949; Table Rock, male, December 7, 1959; two, near Ashland, both sexes, November 1, 1964. The Rufous-sided Towhee is a common permanent resident in the Lower Rogue River and Bear Creek valleys up to about $762 \mathrm{~m}$, except in the extreme southeastern portion of the county in the Chaparral-Oak Community where it is uncommon.

Pipilo fuscus. Brown Towhee.

Specimens: Two, $25.7 \mathrm{~km}$ SW Prospect, male, November 13, 1959, and female, November 11,1959 . The Brown Towhee is a fairly common to uncommon permanent resident in the Chaparral-Oak Community of the Lower Rogue River and Bear Creek valleys and foothills. 
Calamospiza melanocorys. Lark Bunting.

Accidental. A male Lark Bunting was seen feeding with a flock of Brewer's Blackbirds at White City on November 13, 1961 (Aud. Field Notes 1962:68). An adult male and an immature of this species were reported near Yaquina Head (Lincoln County) on August 6, 1969 (Aud. Field Notes 1969: 68). The A.O.U. Check-list (1957) gives central California as the closest casual record to Jackson County.

Passerculus sandwichensis. Savannah Sparrow.

Specimens: Four, near Prospect, both sexes, March and April; Medford, female, February 12, 1965; six, Hoover's Lakes, March, April, and May. The Savannah Sparrow is a common permanent resident and breeds in open grasslands in the Lower Rogue River and Bear Creek valleys. It is a very common spring and fall migrant and is especially numerous during migration in the Agate Desert and in the vicinity of White City.

Ammodramus savannarum. Grasshopper Sparrow.

Photographs: Five, Hoover's Lakes, June 2, 1963 (JH). This species is known only from records of birds observed at Hoover's Lakes during the spring and summer of 1963 where one was discovered on May 30. Two were observed carrying food in the same area on June 2 and 6 , but no nest could be located. Lone birds were seen on June 17 and 26, both carrying food. An immature was observed on August 15 in the same area (Richardson and Sturges 1964). Gabrielson and Jewett 1940) list a specimen taken at Robinette (Baker County) on June 22, 1916.

Pooecetes gramineus. Vesper Sparrow.

Specimens: $12.9 \mathrm{~km}$ SW Prospect, male, May 24, 1947; JacksonKlamath County boundary near Pinehurst, sex ?, May 10, 1964. This sparrow is a fairly common summer resident, occurring in the mountains in Mixed Conifer Forest during the breeding season and in the valley during migration. It arrives in late February to March and departs in late September or early October.

Chondestes grammacus. Lark Sparrow.

Specimens: $12.9 \mathrm{~km}$ SW Prospect, male, September 22, 1950; 16.1 km SW Prospect, sex ?, May 1, 1946; Ashland, male, June 1, 1968. The Lark Sparrow is a fairly common permanent resident in the Lower Rogue River and Bear Creek valleys and foothills of the Chaparral-Oak Community. It is less common during winter.

Amphispiza bilineata. Black-throated Sparrow.

Accidental. This species has been observed on the south slope of Roxy Ann Peak where it was first discovered on May 30, 1970. Two birds were banded (after hatching year) there on June 7 (sexes unknown) and on June 17, 1970 (male). Gabrielson and Jewett 
(1940) cite two summer specimens of Black-throated Sparrow from Harney County and Brown (1960) observed the species on several dates in May and June at Nilakishi Ridge (Klamath County) and state that one bird appeared to be gathering nesting material on June 3, 1959. Dubois (1959) saw one near Beaverton and two near Milwaukie (northwestern Oregon) in May and one at Depoe Bay (Lincoln County) on June 4-6, 1959. A bird was observed in Curry County (Brookings ?) on May 23, 1970 (Aud. Field Notes 1970:638). An adult male of the species was collected on a farm near Lebanon (Linn County) on May 3, 1970 (Scott et al. 1972).

Junco hyemalis. Dark-eyed Junco.

Specimens: Numerous specimens from Prospect area, Medford, and Ashland, both sexes, all months. The Dark-eyed Junco is a common breeding bird in the Mixed Conifer Forest of the county. It winters in the low elevations of the Mixed Conifer Forest and Chaparral-Oak Community, arrives in Bear Creek Valley in late October, and departs by April.

Spizella arborea. Tree Sparrow.

A Tree Sparrow was reported at Ashland on January 30, 1965. Other records of this species from western Oregon are three birds seen in the southern Willamette Valley in winter and spring (Gullion 1951) and one that was banded and photographed near Corvallis (Benton County on November 18, 1962; Strauch 1963). Gabrielson and Jewett (1940) list the species as an irregular winter resident in Oregon occurring from October through March.

Spizella passerina. Chipping Sparrow.

Specimen: Prospect, male, May 8, 1934. The Chipping Sparrow is a common migrant and breeding species. It breeds throughout most of the Mixed Conifer Forest in mountain meadows and open ponderosa pine from $610 \mathrm{~m}$ to near timberline. Earliest, February 20, Ashland; latest, October 7, Medford.

Spizella atrogularis. Black-chinned Sparrow.

Accidental. Two birds were discovered on the chaparral covered slope of Roxy Ann Peak on June 7, 1970. A female (after hatching year) was banded there on June 18 and three others were observed on July 2, 1970. A singing male was seen at the same location from May to July 10,.1971. Gabrielson and Jewett (1940) do not list this species.

Zonotrichia querula. Harris' Sparrow.

Specimen: Ashland, male, May 10, 1962. This species is a rare visitor to Jackson County. Two additional specimens taken near Medford on February 1-2, 1912, are reported in Gabrielson and Jewett (1940). There are several sight records of individual birds at a feeder 
at Central Point (Richardson and Sturges 1964). The Harris' Sparrow may occur almost annually during winter in small numbers, especially at feeders, and has been reported at Ashland and Phoenix in April.

Zonotrichia leucophrys. White-crowned Sparrow.

Specimens: Two, $12.9 \mathrm{~km}$ SW Prospect, male and sex ?, April 16, 1947, and September 14, 1951; $3.2 \mathrm{~km}$ N Prospect, male, April 19, 1934; Ashland, male, April 25, 1965. This sparrow is a very common winter resident in the Lower Rogue River and Bear Creek valleys and foothills. Earliest, September 14, Prospect; latest, April 25, Ashland.

Zonotrichia atricapilla. Golden-crowned Sparrow.

Specimens: Five, Ashland, both sexes, October, February, April; Prospect, sex?, October 8,1961 . This species is a very common winter resident in the Lower Rogue River and Bear Creek valleys and foothills. Earliest, September 8, Medford; latest, May 15, Medford.

Zonotrichia albicollis. White-throated Sparrow.

Specimens: Two, $12.9 \mathrm{~km}$ SW Prospect, male, September 18, 1951, and male, May 2, 1953. The White-throated Sparrow is an uncommon migrant and winter resident in the Lower Rogue River and Bear Creek valleys. It is most of ten observed during winter when it may occasionally visit feeders with other species in the genus Zonotrichia. The species has been reported at Ashland, Talent, Phoenix, and Medford.

Passerella iliaca. Fox Sparrow.

Specimens: Two, SW Prospect, female, May 2, 1953, female and sex?, November 26, 1945. The Fox Sparrow is a fairly common winter resident in the Lower Rogue River and Bear Creek valleys and foothills and is a fairly common breeding species in the high Cascades. Gabrielson and Jewett (1940) consider the species a breeding bird in both the Cascade and Siskiyou mountains.

Melospiza lincolnii. Lincoln's Sparrow.

Specimens: $12.9 \mathrm{~km}$ SW Prospect, sex?, September 26, 1949; Ashland, male, April 26, 1965. Gabrielson and Jewett (1940) list a specimen taken at Medford on April 23 (year not given), and one taken at Ashland on May 6, 1914. The Lincoln's Sparrow is an uncommon summer resident in the Cascade Mountains that probably breeds at Howard Prairie. It is a fairly common winter resident and migrant in Bear Creek Valley and at White City.

Melospiza georgiana. Swamp Sparrow.

Accidental. A Swamp Sparrow was observed singing near Shady Cove on April 5, 1969. The species was reported at Eugene (Lane County) on December 29, 1968 (Aud. Field Notes 1969:513). A female of this species collected at Tillamook (Tillamook County) on November 29, 1955 (Burleigh 1957) is the first Oregon specimen. 
Melospiza melodia. Song Sparrow.

Specimens: Five, $12.9 \mathrm{~km} \mathrm{SW}$ Prospect, both sexes, December, January, February; Medford, male, October 18, 1969; Ashland, male, May 4, 1969. The Song Sparrow is a common permanent resident in the Mixed Conifer Forest of some foothill stream valleys and slightly more common along streams and marshes in the Lower Rogue River and Bear Creek valleys.

Calcarius lapponicus. Lapland Longspur.

Accidental. Nine birds were observed at Agate Reservoir on January 26 to February 1, 1971, by several persons. 


\section{ACKNOWLEDGMENTS}

I thank all who have contributed in any way to the completion of this report. Among the many individuals who allowed me use of their unpublished field notes, I thank Thomas McCamant, the late Carl Richardson, Franklin W. Sturges, and Otis Swisher. I also thank Dorothy Tompkins and Joseph $\mathrm{H}$. Hicks, who, in addition to providing unpublished notes, allowed review and inclusion of data from their color slide files. Photographic records cited in the species accounts are acknowledged by their respective initials-DT and JH.

Use of the Carl Richardson Bird and Mammal Collection at Southern Oregon College, Ashland, Oregon is most appreciated.

I am grateful to Charles F. Yocom, for his encouragement during the early stages of compiling the data, to Stephen P. Cross and Franklin W. Sturges, for their suggestions and critical reading of an earlier version of the manuscript, to Richard C. Banks and Marshall Howe who made many helpful suggestions in later revisions, and to Van T. Harris and Rosetta M. Johnson who edited the manuscript.

I thank Karen Pfister who typed the manuscript and Claudia Austin who prepared the map of Jackson County. Habitat figures were generously supplied by the Bureau of Land Management, Medford (Figs. $2-4,6)$ and the Rogue River National Forest (Figs. 5 and 7). 



\section{LITERATURE CITED}

Alderson, G. 1960. The status of the Great Gray Owl in southwestern Oregon. Murrelet $41(2): 28$.

Alderson, G. 1961. Inland occurrences of the Red Phalarope in Oregon. Condor 63(1):97-98.

American Ornithologists' Union. 1957. Check-list of North American birds, fifth ed. Baltimore, Am. Ornithol. Union. $691 \mathrm{pp}$.

American Ornithologists' Union. 1973. Thirty-second supplement to the American Ornithologists' Union check-list of North American birds. Auk 90(2):411-419.

ArbIB, R. S., Jr. 1957. The New York state standards of abundance, frequency, and seasonal occurrence. Aud. Field Notes 11(1):63-64.

Atwood, W. W. 1940. The physiographic provinces of North America. Boston, Ginn and Company. $535 \mathrm{pp}$.

BAlLeY, V. 1936. The mammals and life zones of Oregon. U.S. Dep. Agr., Bur. Biol. Surv., N. Am. Fauna No. 55. 416 pp.

Bertrand, G. A., J. M. Scott, and J. Butler. 1973. American Redstart (Setophaga ruticilla) breeding in southwestern Oregon. Murrelet 54(2):24.

BRown, R. McP. 1960. Black-throated Sparrow in south-central Oregon. Condor $62(3): 220-221$.

BrowniNG, M. R. 1966a. Range additions of several species of birds in southwestern Oregon. Murrelet 47(2):50-51.

Browning, M. R. 1966b. Additional records on the birds of southwestern Oregon. Murrelet 47(3):76.

Browning, M. R. 1972. Second inland specimen of the Ancient Murrelet for Oregon. Murrelet $52(3): 42$.

Browning, M. R, AND W. English. 1967a. Anna's Hummingbird in southwestern Oregon. Condor 69(1):89.

Browning, M. R., ANd W. English. 1967b. Possible Yellow-shafted Flicker in southwestern Oregon. Condor $69(2): 210$.

BURLeigh, T. D. 1957. Unusual early winter records from Oregon. Condor $59(3): 209$.

Detling, LeR. E. 1961. The chaparral formation of southwestern Oregon, with considerations of its postglacial history. Ecol. 42(2):348-357.

Dice, L. R. 1943. The biotic provinces of North America. University of Michigan Press, Ann Arbor. 78 pp.

Dicken, S. N. 1959. Oregon geography. Third ed. Ann Arbor, Edwards Bros., Inc. $140 \mathrm{pp}$

DuBois, H. M. 1959. Black-throated Sparrows in northwestern Oregon. Condor $61(6): 435$.

EvendeN, F. G., Jr. 1947. Anthony's Green Heron nesting in western Oregon. Auk $64(2): 322-323$.

Evenden, F. G., Jr., P. C. Dumas, and K. L. Gordon. 1947. The Black Phoebe in western Oregon. Condor 49(5):212. 
Evenden, F. G., Jr., D. B. Marshall, and T. H. McAllister, JR. 1950. Waterfowl populations of a swamp in western Oregon. Condor 52(4):159-163.

Farner, D. S. 1952. The birds of Crater Lake National Park. University of Kansas Press, Lawrence. $187 \mathrm{pp}$.

Fender, K. M. 1951. Notes on the western Mockingbird. Murrelet 32(2):29.

Franklin, J. F., ANd C. T. Dyrness. 1973. Natural vegetation of Oregon and Washington. USDA Forest Serv. Gen. Tech. Rep. PNW-8. $417 \mathrm{pp}$.

Gabrielson, I. N. 1931. The birds of the Rogue River Valley, Oregon. Condor $33(3): 110-121$.

Gabrielson, I. N., and S. G. Jewett. 1940. Birds of Oregon. Oregon State Monogr. No. 2. Oreg. State Coll. Corvallis. $650 \mathrm{pp.}$

Gruss, L. W. 1958. Occurrence of the Yellow-shafted Flicker in northern California. Condor 60(3):193.

Grinneli, J., ANd A. H. Miller. 1944. The distribution of birds of California. Pac. Coast Avif. 27. $608 \mathrm{pp}$.

Gullion, G. W. 1947. Additional notes on cranes in the Cascade Mountains of Oregon. Condor 49(3):128.

Gullion, G. W. 1948. Crane migration in the Willamette Valley, Oregon. Condor $50(4): 165$.

Gullion, G. W. 1951. Birds of the southern Willamette Valley, Oregon. Condor $53(3): 129-149$.

HydE, A. S. 1940. Western Mockingbird and Desert Sparrow in southwestern Oregon. Condor $42(6): 305$.

JEweT, S. G. 1930. Notes on the Dowell Bird Collection. Condor 32(2):123-124.

JEW ETT, S. G. 1942. Some new bird records from Oregon. Condor 44(1):36-37.

JEwETT, S. G. 1945. Breeding of the Green Heron in northwestern Oregon. Condor $47(5): 219$.

JEwETT, S. G. 1949. The Franklin Gull in Oregon. Condor 51(4):189-190.

JEwET, S. G. 1951. An ancient murrelet goes inland. Condor 53(6):301.

KEBBE, C. E. 1958a. Inland occurrences of Black Brant in Oregon. Murrelet $39(1): 13$.

KеввE, C. E. 1958b. Nesting records of the Red-necked Grebe in Oregon. Murrelet $39(1): 14$.

KrIDLER, E. 1965. Records, obtained while banding, of birds unusual in southeastern Oregon. Auk 82(3):496-497.

Kridler, E., AND D. B. Marshall. 1962. Additional bird records from southeastern Oregon. Condor 64(2):162-164.

Larrison, E. J., JR., and K. G. Sonnenberg. 1968. Washington birds, their location and identification. Seattle, Seattle Aud. Soc. $258 \mathrm{pp}$.

Litthefield, C. D., ANd W. L. Anderson. 1971. Tennessee Warbler observations in Oregon. Calif. Birds 2(4):137-138.

Marshali, D. B. 1959 . New bird records from southeastern Oregon. Condor 61(1):53-56.

McAllistrr, T. H., Jr. 1949. Possible nesting of Blue-winged Teal in the W llamette Valley, Oregon. Condor 51(2):99.

Munz, P. A., ANd D. D. KECK. 1959. A California flora. University of Calif. Press, Berkeley. $1681 \mathrm{pp}$.

PECK, M. E. 1941. A manual of the higher plants of Oregon. Portland, Binford and Mort. $866 \mathrm{pp}$.

Pruits, B. H. 1950. Gnatcatchers in Oregon. Condor 52(1):40.

Randall, W. R. 1964. Manual of Oregon trees and shrubs. Oreg. State Univ. Book Stores, Inc., Corvallis. 234 pp. 
Richardson, C. 1961. Tricolored Blackbirds nesting in Jackson County, Oregon. Condor 63(6): $507-508$.

Richardson, C., and F. W. Sturges. 1964. Bird records from southern Oregon. Condor 66(6):514-515.

Rudd, R. D. 1962. Climate. Pages 31-38 in R. M. Highsmith, Jr., ed. Atlas of the Pacific Northwest. Resources and development. Oregon State University Press, Corvallis.

Scott, J. M., W. A. Thackaberry, and G. A. Bertrand. 1972. Specimen of the Black-throated Sparrow from western Oregon. Murrelet 52(3):41.

ShorT, L. L., Jr. 1965. Specimens of Nuttall Woodpecker from Oregon. Condor $67(3): 269-270$.

Sooter, C. A. 1941. Additional records of the western Mockingbird in Oregon. Condor $43(3): 157$.

Stevenson, J., ANd H. Fitch. 1933. Bird notes from southwestern Oregon. Condor $35(4): 167-168$.

Strauch, J. G., Jr. 1963. A Tree Sparrow in western Oregon. Condor 65(4):330.

Thatcher, V. E. 1947. Cranes and egrets in Douglas County, Oregon. Condor $49(1): 42$.

Thatcher, V. E. 1953. The cowbird in western Oregon. Condor 55(6):318.

U.S. Weather Burkat. 1965. Climatic summary of the United States--supplement for 1951 through 1960, Oregon. Climatography of the United States 86-31. $96 \mathrm{pp}$.

WALKer, A. 1955. Unusual bird records for western Oregon. Murrelet 36(2):29.

W ARING, R. H. 1969. Forest plants of the eastern Siskiyous: their environmental and vegetational distribution. Northwest Sci. 43(1):1-17.

Z rmmerman, D. A. 1973. Range expansion of Anna's Hummingbird. Am. Birds $27(5): 827-835$. 